Portland State University

PDXScholar

\title{
Applying Deception Detection to True and False Confessions: a Novel Approach to Conducting Experiments in Legal Psychology
}

Olivia Preston

Portland State University

Follow this and additional works at: https://pdxscholar.library.pdx.edu/honorstheses

Let us know how access to this document benefits you.

\section{Recommended Citation}

Preston, Olivia, "Applying Deception Detection to True and False Confessions: a Novel Approach to Conducting Experiments in Legal Psychology" (2016). University Honors Theses. Paper 261.

https://doi.org/10.15760/honors.230

This Thesis is brought to you for free and open access. It has been accepted for inclusion in University Honors Theses by an authorized administrator of PDXScholar. Please contact us if we can make this document more accessible: pdxscholar@pdx.edu. 
Applying Deception Detection to True and False Confessions: A Novel Approach to Conducting Experiments in Legal Psychology

by

\section{Olivia Preston}

An undergraduate honors thesis submitted in partial fulfillment of the requirements for the degree of

Bachelor of Arts

in

University Honors

and

Criminology \& Criminal Justice, Psychology

Thesis Adviser

Kris Henning

Portland State University 


\section{Table of Contents}

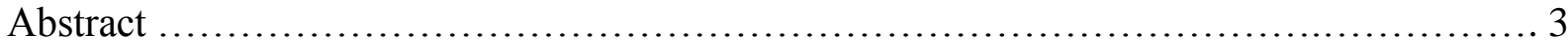

Introduction $\&$ Literature Review............................................... 4

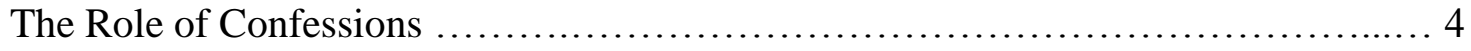

The Impact of False Convictions .......................................... 5

Defining False Confessions ............................................. 7

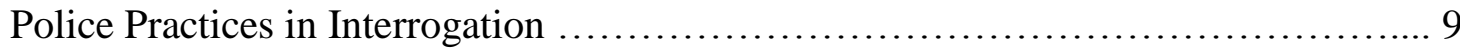

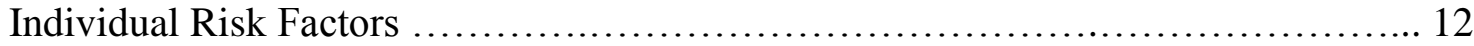

Using Psychological Research to Inform Interrogational Practices ................ 13

Deception Detection in Practice ............................................ 15

Distinguishing Between True and False Statements ............................ 18

Applying Deception Detection to Confessions ............................... 21

Verbal Cues ............................................................ 24

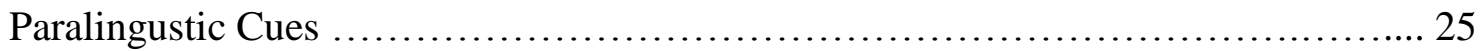

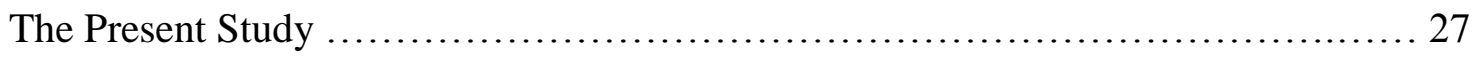

Research Questions ....................................................... 28

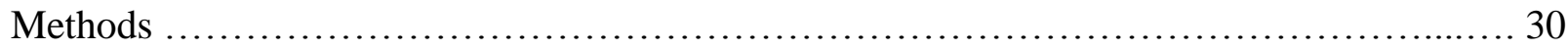

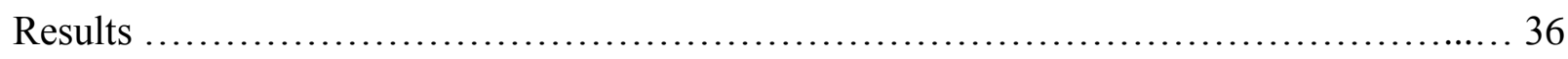

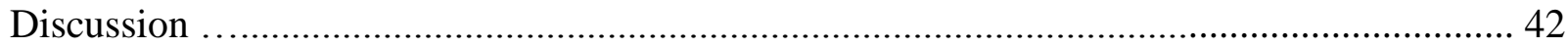

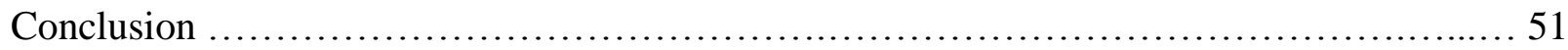

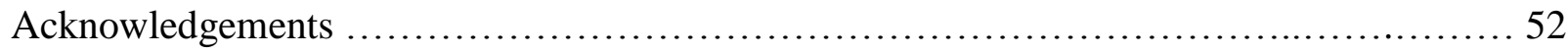

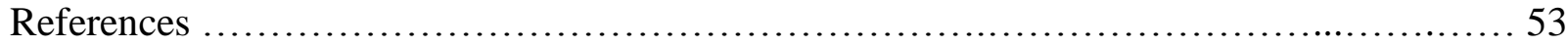




\begin{abstract}
Recent exonerations of convicted defendants by the efforts of advocates like the Innocence Project are accompanied by a concerning finding that a large proportion of defendants had falsely confessed to the alleged crime. False convictions result in due process violations and suffering and stigma by the convicted and their families, in addition to imposing an economic burden on the community. Prior research has identified structural interrogation practices and individual characteristics that increase risk of false confessions, however knowledge on how to identify true and false confessions is minimal and undeveloped. Cues to deception in false statements may be an effective means of identifying true and false confessions. However, extant research on deception detection has not been fully applied to confessions and paralinguistic cues (e.g. pauses, pitch change) have never been tested. This study examined the efficacy of training in paralingustic cues on the ability to identify true and false confessions. A second goal was to assess the use of an online experimental survey as an alternative to traditional experiments. True and false confessions to guilt-inducing or shame-evoking events were obtained through an adaptation of Kassin, Meissner, \& Norwick's (2005) method. Participants $(n=63)$ from a second sample were randomly assigned to receive training in paralingustic cues to deception or a placebo training. Subsequently, participants rated perceived veracity of six confessions and their confidence level in each judgment. Consistent with prior research, the results indicated that accuracy rates were around chance levels and that confidence was unrelated to accuracy. The accuracy rate of the paralingustic group did not significantly differ from the control group, possibly due to random effects in treatment assignment. The paralingustic group indicated significantly higher confidence than the control group, which highlights a troubling trend that deception detection training increases confidence, but not accuracy in judgment. It is essential for agents in the legal system - law enforcement, legal decision-makers, and forensic psychologists - to be aware of empirically-supported cues to guilt or innocence in confessions in order to prevent false convictions and preserve the legitimacy of the legal system.
\end{abstract}


APPLYING DECEPTION DETECTION TO TRUE AND FALSE CONFESSIONS

\section{Introduction and Literature Review}

In 1989, five black and Hispanic young men from the ages of 15 to 16 were arrested and interrogated for the brutal rape of a white, upper-middle class female in Central Park. After many hours of interrogation, they all confessed to the murder and all were eventually convicted.

Thirteen years later, the real attacker admitted to committing the crime and was matched on DNA to the crime scene. A similar case of false conviction involved 11-year old Lacresha Murray, who was accused of killing a toddler under her supervision in 1996. In interrogation, she stated over 40 times that she did not hurt the toddler, before breaking down and admitting to an accidental killing (Drizin \& Colgan, 2004). A transcript of the interrogation suggests coercion during the interrogation and coaching on the part of the detectives (Krzewinski, 2002). Lacresha was given a 25-year prison sentence before an appeals court threw out her conviction in 1999. These two famous cases, along with many others, have spurred researchers from the fields of criminal justice, legal psychology, social psychology, and communication to ask why individuals confess to crimes they did not commit and how the criminal justice system fails to accurately identify false confessions.

\section{The Role of Confessions}

False convictions are increasingly recognized as an issue of concern for the legal system. The Innocence Project, begun by Northwestern University, has played a prominent role in the recognition of false convictions through their advocacy efforts to exonerate falsely convicted offenders, some from death row. Exoneration has typically resulted after DNA testing, which often was not an available technique during the time of the alleged offense, but also through further investigation that revealed the true perpetrator or an alibi of the convicted individual (Drizin \& Leo, 2004). The strength of the Central Park Five and the Lacresha Murray cases 
against the accused lay in the presence of a confession. In 15-20\% of DNA exonerations of falsely convicted individuals, the evidence against the defendant included the presence of a confession or admission to the crime (Drizin \& Leo, 2004; Garrett, 2010; Scheck, Neufled, \& Dwyer, 2000), with even higher rates in capital cases (White, 2003).

A confession plays an important role in the decisions of judges and jury members. Legal researchers have found that confession evidence leads to an increased likelihood of conviction, even if the defense is able to present evidence indicating innocence and to demonstrate that the confession was obtained through coercive means (Leo \& Ofshe, 1998). Leo and Ofshe (1998) reviewed 60 case studies of false convictions, finding that evidence indicating innocence was overlooked or disregarded by judicial decision-makers when the accused had confessed to the crime. Through an experimental study, Kassin \& Neumann (1997) tested the weight of confession evidence in comparison to eyewitness identification and character testimony. They found that confession evidence was more incriminating than other types of evidence and produced the highest rates of conviction. Thus, confession evidence is extremely important to judicial decision-making. These findings can be corroborated by research indicating that confessions, regardless of whether or not they are true, are more readily believed than denials and judged as more honest (Levine, Kim, \& Blair, 2010). Difficulty in assessing veracity (i.e. truthfulness) appears to be a contributed to an inability to detect false confessions, as judges and other legal decision-makers tend to focus on inaccurate cues to veracity when judging the credibility of a defendant (Porter \& ten Brinke, 2009).

\section{Impact of False Convictions}

It is important to identify true and false confessions - at key points of the judicial process such as interrogation, the prosecutorial decision to charge, the trial, or the appeal - in order to 
APPLYING DECEPTION DETECTION TO TRUE AND FALSE CONFESSIONS

protect the innocent against wrongful conviction and to maintain the legitimacy of the criminal justice system. Wrongful convictions constitute a deviation from the presumed fairness and due process of the legal system, which leads to a decreased perception of legitimacy (Williams, 2000). The $5^{\text {th }}$ and the $14^{\text {th }}$ Amendments to the Constitution guarantee a right to due process in criminal justice proceedings, which researchers like Leo (2008) have indicated was lacking in many interrogations leading to false confessions. False confessions have only recently been brought to the forefront of the legal psychology research due to the recent exonerations of falsely convicted individuals, however researchers throughout the $20^{\text {th }}$ century had raised the issue that police-induced false confessions are one of the leading causes of miscarriages of justice in America (Bedau \& Radelet, 1987; Borchard, 1932).

Beyond violating the due process protection of the innocent, false convictions are harmful to the community. First, the criminal justice system spends time and resources in the process of trying and convicting suspects. An enormous amount of money is spent in incarcerating one individual, estimated to be $\$ 30,619$ annually in the federal system (Federal Registrar, 2015). False convictions have not only ramifications for the individual and the legitimacy of the criminal justice system, but also economic implications for the expenditures of the legal system and the taxpayers in the community that fund the system. Additionally, falsely convicted individuals have been awarded large amounts of money through civil suits against the state after exoneration (e.g. Drizin \& Leo, 2004).

Second, wrongful convictions hold severe consequences for the families of the convicted, who are called "secondary victims" of wrongful convictions in a study examining the consequences of false convictions conducted by Jenkins (2013). Jenkins' qualitative study involved interviewing 132 individuals affected by false convictions, including 27 falsely 
APPLYING DECEPTION DETECTION TO TRUE AND FALSE CONFESSIONS

convicted individuals or "primary victims". He found that "secondary victims" - spouses, children, and families - often suffer from psychological effects like anxiety, depression, panic attacks, or post-traumatic stress symptoms and from financial hardship due to loss of income and legal fees (Jenkins, 2013). While some families become estranged or disintegrate due to the legal persecution and incarceration of the convicted family member, others persist in believing in the innocence of the convicted family member. Further, even families that clung together through the appeals process and the eventual release can experience severe consequences after exoneration, such as difficulties for children in communicating or for a spouse in salvaging the relationship with the "primary victim".

False convictions and the subsequent harm to the individuals, families, and the community need to be prevented. One approach is to develop better strategies for identifying false confessions because such confessions are often the 'nail in the coffin' for falsely accused individuals, as judicial decision-makers are unable to look past confession evidence. Many actors in the legal system have responsibility to identify false confessions and circumstances that may elicit false confessions. This includes police officers, detectives, prosecutors, judges, and jury members, but also psychological experts who may play a role in the legal process. Psychologists are often retained to diagnose a defendant's mental state (e.g. competence, insanity) or evaluate dangerousness or likelihood to recidivate (Tillbrook, Mumley, \& Grisso, 2003). In order to conduct an accurate evaluation, psychologists may also need to assess psychological effects of interrogation (Volbert \& Banse, 2014), and to understand who may be at increased risk of giving a false confession due to individual characteristics. In sum, it is essential for all agents in the legal system, including psychologists, to be aware of false confessions and to have knowledge of risk factors and cues to guilt or innocence. 
APPLYING DECEPTION DETECTION TO TRUE AND FALSE CONFESSIONS

\section{Defining False Confessions}

The most influential shift in false confession research was made by Kassin $\&$ Wrightsman's (1985) chapter, Confession Evidence, which set the stage for future research by arguing for multiple causes of false confessions. Prior to this chapter, research had not examined interactions between multiple individual and situational factors that may result in false confessions. For instance, Bem (1966) conducted experimental studies on false confessions that were attributed to the idea of self-persuasion or internalization of a false event due to the approach of the interrogator. The concept of self-persuasion was explained through cognitive dissonance - a change in attitude, belief, or behavior resulting from motivation to maintain cognitive consistency in the face of conflicting ideas (Festinger, 1957). Contemporaneous events such as American soldiers during the Korean War growing to believe the false confessions they had given as prisoners of war partially influenced researchers' focus on cognitive dissonance (Brehm \& Cohen, 1962).

In Confession Evidence, Kassin and Wrightsman delineated three types of false confessions made in the context of criminal investigations: voluntary, coerced-compliant, and coerced-internalized. Voluntary confessions are confessions that occur outside of an interrogational context without specific elicitation. Voluntary false confessions usually indicate underlying psychological disturbances, as has been seen in high profile crimes like the Lindbergh kidnapping in the 1930s or the JonBenet Ramsey murder in the 1990s where multiple individuals came forward with false confessions to the crimes (Leo, 2008). Coerced-compliant false confessions are made when a suspect falsely admits his or her guilt to law enforcement because of extreme methods, stress, pressure, or coercion in the interrogation context, but in actuality, they continue believe in their own innocence. Coerced-internalized confessions characterize 
APPLYING DECEPTION DETECTION TO TRUE AND FALSE CONFESSIONS

those confessions made by suspects that come to believe that they actually committed the offense. As indicated by Kassin and Wrightsman (1985), the likelihood of coerced-compliant and coerced-internalized confessions in interrogation can be increased due to certain factors in both the interrogational context and within the individual.

\section{Police Practices in Interrogation}

The reasons for why innocent people give false confessions has been approached primarily from the perspective of legal psychology and applied social psychology. Comprehensive assessments of false confessions have focused on psychological processes of structural practices in interrogation, and individual factors. The most influential guide to interrogation, Criminal Interrogations and Confessions by Inbau, Reid, Buckley, \& Jayne (2001), provides a multi-step approach to getting a suspect to confess, which uses three processes: (1) isolation in order to increase anxiety and a desire to escape, (2) confrontation that includes accusations and citing real or false evidence against the suspect, and (3) minimization in which the investigator justifies the crime and implies leniency in consequences once the suspect confesses. These three situational processes are described by Kassin (2008) in terms of how they may pressure an innocent and susceptible suspect to confess. The presentation of false evidence against the suspect is particularly potent in inducing people to internalize blame and provide a false confession, as was demonstrated through an experimental study by Kassin \& Kiechel (1996). Importantly, Criminal Interrogations and Confessions also provides lie detection training in verbal, nonverbal, and behavioral cues to deception. However, the goal of the training is to detect when a suspect may be lying by providing exculpatory statements (i.e. statements that clear a suspect from alleged guilt), not when a suspect may be lying by providing false confessions. 
APPLYING DECEPTION DETECTION TO TRUE AND FALSE CONFESSIONS

Regarding the interrogational process, Kassin, Leo, Meissner, Richman, Colwell, Leach, and La Fon (2007) conducted an extensive review of police practices in interrogation and their beliefs about interrogational practices - the first study to use a self-report survey to assess police interrogation techniques. The researchers surveyed 631 investigators across 16 police departments in the United States and Canada with the goal describing the law enforcement's perspective on police interrogations and false confessions. The findings indicated that investigators with more years of experience, special interrogational training, and greater confidence in their own deception detection skills were more likely to presume guilt, endorse more interrogational techniques, and to more frequently use psychological manipulation and confrontation in interrogation. In terms of extant interrogational techniques, four factors of interrogation were isolated through factor analyses: (1) isolation, rapport, and minimization, (2) confrontation, (3) threatening the suspect, and (4) presentation of evidence. Under the first factor, interrogational practices included sympathy, self-interest, developing a rapport, and minimizing the offenses, as well as isolating the suspect. Confrontation practices include contradicting what the suspect says, confronting the suspect, and interrupting denials.

Threatening practices circulated around threatening the suspect with punishment, demonstrating frustration and anger, and physically intimidating the suspect. Finally, presentation of evidence against the suspect may include failed polygraph exam results, eyewitness testimony or crime scene photographs - which may be true or fabricated by the interrogator.

Kassin et al. (2007) also examined the investigators' perceptions of the prevalence of false confessions. Investigators indicated an average interrogation length of 1.6 hours with their longest interrogation lasting an average of 4.2 hours. This finding is disproportionately shorter than the average 16.4 hours of interrogation time in known false confession cases reviewed by 
APPLYING DECEPTION DETECTION TO TRUE AND FALSE CONFESSIONS

Drizin and Leo (2004). Drizin and Leo (2004) found that known false confessions occurred in extraordinarily lengthy interrogations - quite longer than normative police interrogation time. In the Kassin et al. (2007) study, interrogators provided their own estimate of the self-incrimination rate for innocent suspects, which was an average of $4.78 \%$ or nearly five out of every 100 confessions. Investigators themselves recognize the existence of false confessions, however it is unclear how investigators' decision or confidence that a confession is true or false is related to an actual ability to detect false confessions.

In the case of the Central Park 5, multiple coercive interrogation practices were apparently implemented by interrogations (Drizin \& Leo, 2005). Two of the youth had been interrogated throughout the night and the following day after their arrest. Although the confessions were recorded on video, the earlier interrogation sessions leading up to the confessions were not recorded. Throughout the trial, the youth and their families describes highly coercive interrogations with physical slapping, yelling, and cursing. Several of the youth were promised to be released from custody if they confessed to the crime, while one, Antron McCray, was told that he would be treated as a witness, not as a suspect, if he admitted to participating in the rape. One of the interrogating officers - Detective Thomas McKenna - later described how he falsely told one of the youth - Yusef Salaam - of how his fingerprints were found on the jogging shorts of the victim (Sullivan, 1990).

In addition to structural interrogation practices, stress due to police pressure certainly has an additional influence on risk of false confessions (Ofshe \& Leo, 1997; Gudjonsson, 2003). However, researchers have suggested that the single strongest technique that induces false confessions is the promises of leniency if the suspect confesses and promises of more punitive outcome if the suspect does not (Leo, 2008). This forces a suspect to balance the immediate 
APPLYING DECEPTION DETECTION TO TRUE AND FALSE CONFESSIONS

benefits of falsely confessing against the eventual risk and cost of prosecution. Those suspects who believe that their innocence will eventually be brought to light despite a false confession in the immediate future are more likely to give a false confession in interrogation (Gudjonsson, 2003; Kassin, 2005).

\section{Individual Risk Factors}

It is important to note that not everyone may be equally at risk for giving a false confession because individual characteristics may contribute to falsely confessing above and beyond a coercive interrogational context. Youth and intellectual disability tend to be risk-factors for false confessions. Intellectual disability (previously called mental disability or mental retardation) and lower Intelligence Quotient scores increase likelihood of falsely confessing in interrogation (Leo, 2008; Kassin, Drizin, Grisso, Gudjonsson, Leo, \& Redlich, 2010) because of impairments in cognitive processing and increased compliancy (Drizin \& Leo, 2004). Drizin and Leo (2006) indicated an overrepresentation of youth as known false confessors, because juveniles tend to be more impulsive and less able to perceive future risk and long-term consequences (Owen-Kostelnik, Reppuci, \& Meyer, 2006). The presence of a serious mental illness and drug intoxication also increase risk of falsely confessing for a suspect (Redlich, Kulish, \& Steadman, 2011; Sigurdsson and Gudjonsson (1996).

Personality traits of compliancy and suggestibility may result in individuals changing their memory based on what they are told under pressure (Gudjonsson, 2003) and developing a belief that they actually committed the act that they are accused of committing - resulting in the coerced-internalized confession type indicated by Kassin \& Wrightsman (1985). Experimental studies designed to test the ability of individuals to internalize suggested events have implemented false memories such as being attacked by an animal (Porter, Yuille, \& Lehman, 
APPLYING DECEPTION DETECTION TO TRUE AND FALSE CONFESSIONS

1999), or cheating on a recent test (Russano, Meissner, Narchet, \& Kassin, 2005). Shaw and Porter (2015) found that in their false memory experiment that $70 \%$ of their participants internalized (i.e. grew to believe) a false memory over multiple interrogational sessions about committing a criminal event in their past (i.e. assault, assault with weapon, or theft) which had been corroborated by evidence fabricated by the researcher.

These experimental studies raise concerns about the ease of internalization of false confessions in the context of a confident interrogator, repeated interrogations, and corroboration by external sources that serves as evidence. Biases of interrogators, coercive structural interrogation practices, and individual risk factors may elicit false confessions during interrogation. These findings have indicated the need for more objective, empirically-based interrogation techniques that can also provide a safeguard against false confessions.

\section{Using Psychological Research to Inform Interrogational Practices}

In contrast to prevalent interrogational practices that may increase risk of false confessions, researchers has advocated for the use of psychological research to inform sound interrogational practices. Two broad approaches to conducting interrogations have been suggested in order to accurately identify deceptive exculpatory statements, while minimizing coercive practices that may elicit false confessions. The approaches entail the strategic-use of evidence (SUE) technique and the theory of cognitive load (Blandón-Gitlin, Fenn, Masip, \& Yoo, 2014). These approaches differ from extant interrogational practices conducted by law enforcement by relying on cognitive psychological research and by providing a context for truthful statements to be identified by the nature of their statement.

The SUE technique involves the strategic disclosure of incriminating evidence in order to test for statement inconsistencies and has been validated through several experiments (Hartwig, 
APPLYING DECEPTION DETECTION TO TRUE AND FALSE CONFESSIONS

Granhag, Strömwall, \& Kronkvist, 2006). However, the incriminating evidence should be real, rather than false. Meissner \& Kassin (2004) advise against the method of presenting false evidence, which can take the form of an alleged failed polygraph, fingerprint, hair sample, or eyewitness because presenting false evidence can influences both guilty and innocent confessions. It is not unreasonable to suppose that some of the individual risk factors - juvenile status, intellectual impairment, or intoxication - may increase the risk of innocent suspect of perceiving incontrovertible evidence against them and eliciting feelings of hopelessness.

The concept of cognitive load is based on the premise that additional cognitive work is necessary to facilitate a lie in comparison to telling the truth because lying is more demanding of cognitive processes (Blandón-Gitlin et al., 2014). Telling a deceptive story is more cognitively taxing because the deceiver needs to formulate the lie and mask the truth, in addition to monitoring their own demeanor and behavior to appear honest to the interviewer (DePaulo \& Kirkendol, 1989) and monitoring the interviewer's reactions and behavior to access their own success at deception (Buller \& Burgoon, 1996). It is important to note that practical safeguards, such as video-recoding of interrogations, are additionally necessary to minimize coercive police interrogations (Kassin, Appleby, \& Perillo, 2010).

Although the theory of cognitive load has only received wide attention recently (Vrij, Fisher, Mann, \& Leal, 2006), researchers have begun to test multiple techniques designed to increase cognitive load. Walczyk, Schwartz, Clifton, Adams, Wei, \& Zha (2005) suggest asking a suspect close-ended questions under time pressure. (Evans, Michael, Meissner, \& Brandon, 2013) tried to increase cognitive load by asking participants to describe events in their second language, rather than their primary language. Vrij, Mann, Fisher, Leal, Milne, \& Bull (2008) conducted two studies that increased cognitive load for "suspects" by asking them to recount 
their stories in reverse order (i.e. starting from the end of the story and tracing the steps backwards to the beginning). The reverse-order stories that were false contained more cues to deception in comparison to a control group that told their stories in chronological order from beginning to end. Furthermore, police officer participants that assessed veracity where $18 \%$ more likely to detect deception when considering reverse-order false stories in comparison to chronological false stories (60\% accuracy in comparison to $42 \%$ accuracy).

The principle of cognitive load may provide an effective psychological framework for developing deception detection techniques. The cognitive load for a suspect who is telling a truthful statement will be different from the cognitive load for a suspect who is telling a deceptive statement due to increased cognitive processing needed to tell a false story (Vrij et al., 2008; Blandón-Gitlin et al., 2014). As will be indicated later, cognitive load also is the psychological basis for empirically-supported deception detection cues that can be used to distinguish between true and deceptive statements.

\section{Deception Detection in Practice}

Deception detection is necessary for investigators and judicial decision-makers to evaluate the guilt or innocence of a suspect. Unfortunately, considerable research across a variety of individuals - law enforcement officers, judges, jury-members, college students - suggests that participants are generally poor at detecting deception, doing so around chance levels, both in social contexts and criminal interrogations (Akehurst, Köhnken, Vrij, Bull, 1997; Bond \& DePaulo, 2006; Bond \& DePaulo, 2008; DePaulo, Lassiter, \& Stone, 1982; Ekman \& O’Sullivan, 1991; Memon, Vrij, \& Bull, 2003; ten Brinke \& Porter, 2013; Vrij, 2000). Vrij (2000) concluded that accuracy rates of professional investigators range from $45 \%$ to $60 \%$, averaging around 54\% accuracy. A meta-analysis of 108 studies on deception detection by 
APPLYING DECEPTION DETECTION TO TRUE AND FALSE CONFESSIONS

Aamodt \& Custer (2006) concluded that individual differences, including age, gender, education, law enforcement experience, and confidence were all unrelated to the ability to detect deception. These unimpressive findings regarding deception detection by professionals and laypersons emphasize the importance of finding an objective means of identifying deception and implementing effective training in deception detection. Unfortunately, researchers have also found that deception detection accuracy does not appear to increase with experience or training (DePaulo \& Pfeifer, 1986; Leach, Talwar, Lee, Bala, Lindsay, 2004; Kassin \& Fong, 1999; Köhnken, 1987).

Despite the fact that many professional investigators claim that their experience in interrogation enhanced their skill in detecting deception, Kassin, Norwick, \& Meissner (2005) found that investigators with prior interrogation experience had poorer accuracy than students with no prior interrogation experience in identifying true and false confessions of criminal offenders. Further, there was no relationship between years of experience and accuracy. Investigators had higher confidence in their deception detection abilities - a finding which is supported by other researchers who have found that investigators believe in a "sixth sense" for detecting deception (Leo, 1996), despite no actual correlation being found between level of confidence and accuracy. Further, investigators were more likely to judge make judgements of guilt regardless of veracity by judging both true and false confessions to be "true" as an admission of guilt, demonstrating a "guilt bias". Burgoon, Buller, Ebesu, \& Rockwell (2009) also found a guilt bias on the part of military intelligence investigators because the investigators demonstrated impairment in judging accuracy when investigators suspected that the individual under interrogation was guilty. Their study further indicated that, overall, accuracy rates were higher with identifying true rather than false statements. Despite the "guilt bias" of investigators 
APPLYING DECEPTION DETECTION TO TRUE AND FALSE CONFESSIONS

in interrogation, the participants who are not investigators tend to be more accurate at identifying true statements in comparison to deceptive or false statements (Levine, Park, \& McCornack, 1999; Vrij \& Baxter, 1999). This finding is explained as natural because the majority of statements heard from others - both face-to-face and online - tend to be truthful (Hancock, 2007).

The presumption of guilt on the part of trained investigators sets into motion processes during interrogation that may ultimately serve to confirm interrogators' expectations. Kassin, Goldstein, \& Savitsky (2003) conducted an experimental study with undergraduate students posing as "interrogators" or "suspects" during a mock interrogation. Half of the "interrogators" were led to believe that a suspect was guilt and the other half were led to believe a suspect was innocent. In the experiment, half of the "suspects" were actually guilty of carrying out a mock theft and half were innocent. The results of this 2 (guilty expectation vs. innocent expectation) $\mathrm{x}$ 2 (actual guilt vs. actual innocent) experiment, found that interrogators with guilty expectations were $23 \%$ more likely to judge guilt. Expectations of guilt led to more guilt-presumptive questions and a greater variety of interrogational techniques. Moreover, actual guilt or innocence interacted paradoxically with expectations as interrogators demonstrated more aggression with innocent suspects, which in turn constrained the behavior of the suspects and led the interrogators to perceive guilt.

The confirmation bias in interrogation indicates that plausible denials may be discounted or misinterpreted as investigators will selectively seek and interpret new information in a way that verifies their belief of guilt (Kassin \& Gudjonsson, 2004). Kassin et al. (2003) further suggest that this conformation bias may exacerbate the problem that police interrogators are overconfident in their ability to detect true and false statements. The lack of accuracy in 
APPLYING DECEPTION DETECTION TO TRUE AND FALSE CONFESSIONS

deception detection - demonstrated across investigators and laypersons - raises the question of what methods exist for identifying true and false statements. Do these methods actually increase accuracy of deception detection and, if so, are they applicable specifically to confession statements?

\section{Distinguishing Between True and False Statements}

Identification of true and false confessions has received limited attention from the deception detection field. Experts may hesitate to label a false confession as deceptive due to the lack of outright intent or motivation to profit by deception. Moreover, the deception in an exculpatory statement may differ from deception in a false confession, as suggested by research indicating that advance preparation of a lie may result in a "larger quantity of words", while lying on the spot without advance preparation may result in less words begin said in comparison to a truthful statement (Burgoon \& Qin, 2006).

Although false confessions and deliberate deceptions may differ in intent, both types of false statements share the quality of being falsified as the story provided by the individual is not based on an actual experience and originates internally. Johnson \& Raye (1981) distinguished between externally-originating events that are based on actual experience and internallyoriginating events that are based on a fabrication and suggested that the two types of events are qualitatively different. Their research was based on the Undeutsch hypothesis, which suggests that qualitative and quantitative differences exist between true and deceptive statements (Undeutsch, 1982). Rather than considering that the motivation of the "deception" in true and false confessions excludes them from the category of "deception", the present study sought to connect deception detection research with confessions based on fundamental differences between truthful and false statements. The Undeutsch hypothesis and Johnson \& Raye's (1981)'s 
APPLYING DECEPTION DETECTION TO TRUE AND FALSE CONFESSIONS

categorization of externally-originating and internally-originating events, serve as the foundation for considering deception detection research in the context of true and false confession.

Deception detection research has approached cues to deception in three general directions: nonverbal cues (e.g. eye contact, posture), paralinguistic (also known as vocal or auditory) cues (e.g. pauses, pitch change), and verbal cues (e.g. amount of detail, negative words). Overall, research has failed to support the majority of nonverbal cues to deception detection (Vrij, 2008a). Prior to the 1980s, research focusing on nonverbal deception detection primarily considered behaviors like facial expressions, posture shifting, gaze aversion, movements of the hands and feet (e.g. Ekman \& Friesen, 1969; 1974, Ekman, Friesen, \& O’Sullivan, 1988). Complex and objective methodologies using automatic, computerized technology to assess nonverbal body language like movement and position of the face and hands have even been proposed (Meservy et al., 2005). Despite the expectation of empirical support for a widely accepted nonverbal indicator of deception - micro-expressions (i.e. short-span facial expressions that constitute "emotional leakage" of a lie that cannot be suppressed) - Porter \& ten Brinke (2010) found no published empirical research on micro-expressions. Even the polygraph, which is the most widely used technological device for lie detection, raises concerns among researchers due to a high false positive rate (Vrij, 2008a). The polygraph is an instrument that measures physiological arousal by recording heart rate, blood pressure, breathing rate, and skin conductance (i.e. how easily the skin conducts a small current of electricity due to perspiration) (Bartol \& Bartol, 2015). While the polygraph is used by various government agencies, its lack of acceptance by the general scientific community has led to its being inadmissibility in court as evidence by the prosecution (Myers, Latter, \& Abdollahi-Arena, 2006). 
APPLYING DECEPTION DETECTION TO TRUE AND FALSE CONFESSIONS

The gold-standard for interrogation - the Reid technique - claims an $85 \%$ accuracy level in detecting deception or truth by using a combination of nonverbal cues like gaze aversion or frozen posture, behavioral attitudes like anxiousness or guardedness, and verbal cues like rehearsed-sounding responses (Kassin et al., 2007). The Reid technique has been established as training for hundreds of thousands of investigators across the world (John E. Reid \& Associates, 2004). However, experimental studies have found that training in the Reid technique fails to improve judgement accuracy in distinguishing true and false denials both among college students (Kassin \& Fong, 1999) and among experienced investigators (Meissner \& Kassin, 2002), although the confidence of trained investigators in their judgments increases.

Deception detection training provided to professionals often boasts empirical support, which may contribute to investigators' increased confidence - the strength of their belief that a judgment of truth or deception is accurate. Vrij (2008b) points out that police officers in interrogation focus heavily on nonverbal behaviors, specifically visual cues like gaze, movement, or posture, which is recommended in the Reid method (Inbau et al., 2001), while neglecting to examine the speech of a suspect (i.e. verbal and paralingustic cues). However, when investigators focus on speech-related or verbal cues, their deception detection accurate rates tend to increase in comparison to those simply observing visual behavior (Vrij, 2008a). Further, focusing on speech in interrogation would have a secondary effect of encouraging the suspect to talk, providing additional possible cues to deception, and giving the investigator a wider breadth of speech to examine (Vrij, Mann, Kristen, \& Fisher, 2007).

Many investigators claim that training or years of experiences provide them with an intuitive ability to detect deception (Kassin et al., 2005). Intuitive or subjective deception detection abilities have not been supported by research. Anderson, DePaulo, Ansfield, Tickle \& 
APPLYING DECEPTION DETECTION TO TRUE AND FALSE CONFESSIONS

Green (1999) found that laypeople rely on common-knowledge or cues to deception that are not empirically-supported when making an intuitive judgement of veracity. A study by Garrido, Masip, \& Herrero (2004) found that police officer participants demonstrated a chance probability of detecting deception, while students achieved a higher rate of accuracy, which the researchers attributed to a focus on inaccurate cues to deception. Moreover, intuitive judgement fails to demonstrate test-retest reliability, meaning that the same results are not yielded across different investigators or different points in time, which has been demonstrated in both experimentallymanipulated and naturalistic contexts (Leach, 2006). This further indicates the fallibility of interrogators' confidence in their deception detection accuracy.

Despite the discouraging findings of many studies, the deception detection field has indicated that taking into account or focusing on certain verbal or paralingustic cues can improve deception detection (Vrij, 2008a). For instance, Vrij, Edward, \& Bull (2001) found that direct assessment (i.e. asking if an individual is lying) does not result in accurate identification of deception by police officers, but using empirically-supported cues such as speech hesitations or latency period (i.e. number of words per minute of speech) did result in greater accuracy. These positive findings regarding verbal and paralingustic cues to deception suggest that analyzing the speech of a confession statement for empirically-supported indicators of veracity may provide a way of distinguishing between true and false confessions.

\section{Applying Deception Detection to Confessions}

Several studies have directly examined the applicability of empirically-supported deception detection cues from research to true and false confessions. These studies used content analyses to examine suspect statements (Garrett, 2010; Willén \& Strömwall, 2012; Appleby, Hasel, \& Kassin, 2013) rather than testing the efficacy of deception detection cues in identifying 
APPLYING DECEPTION DETECTION TO TRUE AND FALSE CONFESSIONS

true and false confessions. First, Appleby et al. (2013) conducted a content analysis of false confessions that indicated that false confessions are more than mere admissions of guilt; rather, they contain a rich and textured account of the crime along with an explanation of the motive. Additionally false confessions contain accurate crime details, which tend to be more convincing to juries. However, this inclusion of accurate crime details is suggested to be due to the confrontation of the suspect with evidence such as pictures of the victim or crime scene during interrogation. This process, Appleby et al. (2013) argue, gives the suspect information to draw from when providing the false confession. These findings are supported by a previous content analysis by Garrett (2010), which also found accurate crime details in false confessions that, according to investigators, "only the perpetrator could have known". Appleby et al. (2013) address deception detection cues by qualifying the crime scene details as visual and auditory details. This categorization is consistent with prior research that suggests verbal cues can indicate, contrary to this content analysis, higher levels of truthfulness (Vrij, 2008a). However, as can be seen from the Appleby et al. (2013) and Garret (2010) studies, extensive visual and auditory details - a form of verbal cues to deception - were found in false confessions. This conflicts with the research on true and false statements in general that indicates lower amounts of various types of details (e.g. contextual, spatial) in false statements (Masip, Sporer, Garrido, \& Herrero, 2005).

Willén \& Strömwall (2012) tested the ability of verbal cues to deception to distinguish between true and false confessions of criminal defendants. The researchers sought to find out if two specific measures - Statement Validity Analysis (SVA) or Reality Monitoring (RM) - are able to distinguish between true and false confessions either. The Undeutsch hypothesis of qualitative and quantitative differences between true and false statements formed the basis for 
clinically-developed SVA measure and the empirically-based RM measure (Köhnken, 2004; Johnson, 1988). These two measures were originally intended for determining veracity of victims' stories, but they have been adapted by researchers for use with suspects (Porter \& Yuille, 1995; Sporer, 1997; 2004). Willén \& Strömwall (2012) found that neither measure wholly distinguished between true and false confessions, however certain individual criteria did. As the authors point out, this does not dismiss the validity of those measures, but merely indicates their inapplicability to criminal confessions as obtained in this particular study. Despite this, three of the individual criteria did distinguish between true and false confessions. Consistent with Appleby et al. (2013), remorse or apologies (i.e. self-deprecation) were found at higher rates in false confessions. Willén \& Strömwall (2012) found that higher rates of doubts about testimony are present in false confessions in comparison to true confessions, however, a metaanalysis by Vrij (2008a) failed to confirm that finding. The only other significant criterion was unexpected complications (i.e. tangential or irrelevant information) - more likely to be found in true statements. Again, this criterion received only limited support in Vrij's (2008a) metaanalysis. Studies examining verbal cues have found varied reliability of established cues, such as those from the reality monitoring approach (Masip et al., 2005, Porter \& Yuille, 1996).

In summary, the verbal and the paralingustic cues have gathered more support than nonverbal or body language cues in the deception detection literature, however verbal cues may be differentially related to true and false confessions than to true and false statements in general. In practice, deception detection researchers who aim to increase empirically-based police interrogational practices advise against the use of non-verbal or body language cues in favor of a focus on the speech of a suspect - the verbal and paralingustic cues that may be present (Vrij, 2008; Vrij, Mann, Kristen, \& Fisher, 2007). Porter \& ten Brinke (2010) provide a review of 
APPLYING DECEPTION DETECTION TO TRUE AND FALSE CONFESSIONS

relevant literature on nonverbal, verbal, and paralinguistic cues to deception. In their review, they point out the efficacy of both the verbal and paralinguistic approaches, while concluding that certain paralingustic cues fall among the most supported cues to deception - pauses, repetition, response latency, speech rate. Specific verbal and paralingustic cues associated with deception and truth-telling are summarized below. This study considered both verbal and paralingustic cues to deception for application to true and false confessions. The cues considered in this study were identified based on empirical-support and reliability in the research literature (See Table 1). Ultimately, the verbal cues were dropped from consideration due to estimations of low sample size and concerns about a differential relationship to confessions statements (e.g. Appleby et al., 2013); however, they are presented here for descriptive purposes for consideration by future research.

\section{Verbal Cues}

Research on verbal or linguistic differences in deception detection indicates that deceptive individuals tend to use fewer first-person pronouns or self-references (e.g. "I", "my", “me”), more negative emotion words (e.g. "hate", "worthless", “enemy”) or negative statements, and fewer "exclusive" words that demonstrate a cognitive complexity to a story (e.g. “except", "without", "but”) (Newman et al., 2003). The use of lower self-references is also supported through experimental research by Feeley \& deTurk (1998). Deceptive statements are less likely to be direct, relevant, logically-organized, and clear (DePaulo, Malone, Lindsay, Muhlenbruck, Charlton, \& Cooper, 2003) (i.e. immediacy cues). Fuller, Biros, Burgoon, Nunamaker (2013) found the following constructs associated with deception: lower quantity (e.g. word quantity), lower lexical diversity (e.g. content word diversity, redundancy) and higher 
APPLYING DECEPTION DETECTION TO TRUE AND FALSE CONFESSIONS

uncertainty (e.g. generalizing terms), both of which are supported by additional research (Janux 2014).

\section{Paralingustic Cues}

In comparison to the verbal cues, which require a content analysis of speech, paralingustic cues require attention to the quality of production of the speech itself. Burgoon and Qin (2006), DePaulo et al. (2003), Davis, Markus, Walters, Vorus, \& Conners (2005), Sporer \& Schwandt (2006), Porter \& ten Brinke (2010) indicate that consecutively repeating a phrase or word in speech can be indicative of deception (i.e. repetition). Speech errors fall under the paralinguistic category as research indicating that non-fluent or difficult to understand speech that may include grammatical errors, sentence incompletion, or slips of the tongue may indicate deception (Kraut, 1980; Feeley \& deTurck, 1998; Vrij, 2008a; Zuckerman, DePaulo, \& Rosenthal, 1981). Pitch has also been examined as a cue, with research indicating that higher pitch is associated with deception (Vrij, 2008a). Characteristics of pauses have also been examined with higher frequency of pauses, longer pause duration (i.e. pause within speaker's own speech), response latency (i.e. pause between when an interlocutor stops and the speaker begins to speak), and presence of speech hesitations (e.g. um, uh) within pauses (Vrij, 2008a, Janux, 2014). A variety of studies indicate that the number of words can be an important cue to deception with lower speech time (i.e. time spent talking) associated/predicting with deception (Feeley \& deTurck, 1998, Vrij, 2008a). Studies by Feeley \& deTurck (1998) \& Vrij, Edward, \& Bull (2001) also supported the findings that speech hesitations or latency period (i.e. number of words per minute of speech) can be indicative of deception.

Certain paralinguistic cues like increased latency (i.e. time lapse between question and answer), speech hesitations (use of "ums" "uhs" or "ers"), speech errors, and a slower rate of 
speech are associated with increased cognitive load (Goldman-Eisler, 1968, Smith \& Clark, 1993, \& Sporer \& Schwandt, 2006). Cognitive load, previously mentioned as a focus of interrogational practices relying on empirically-supported psychological research, lends support to the investigation of paralingustic cues to deception in the search for indicators of veracity in confessions, as was done in the present study. However, it is important to note that there does not appear to be broad consensus in the research literature on certain cues. For example, Fuller, Biros, \& Wilson (2008) found that cues of generalizing terms, lexical diversity, and speech time are significant in regression models as predictors of veracity, while cues such as pauses and repetition are not significant. Differences are also observed based on amount of preparation for the lie; for instance, unprepared lies demonstrated a longer response latency period in comparison to prepared lies (Porter \& ten Brinke, 2010). These studies highlight the need for research to further examine the categorization of deception detection cues.

\begin{tabular}{|c|c|c|}
\hline Verbal & Paralinguistic & Placebo/Control \\
\hline $\begin{array}{l}\text { Negative Statements - Higher use of } \\
\text { denials, negative emotion words, or } \\
\text { disparaging statements can indicate } \\
\text { deception. }\end{array}$ & $\begin{array}{l}\text { Pitch - Deceptive individuals are more } \\
\text { likely to have a higher pitch in their } \\
\text { speech. }\end{array}$ & $\begin{array}{l}\text { Personality Disorders (e.g. narcissistic, } \\
\text { borderline, antisocial, or histrionic) - Individuals } \\
\text { with these disorders tend to be more confident } \\
\text { and skilled in lying. }\end{array}$ \\
\hline $\begin{array}{l}\text { Generalizing Terms - Higher use of } \\
\text { generalizing terms like "always", "never", } \\
\text { "nobody" can indicate deception. }\end{array}$ & $\begin{array}{l}\text { Pauses - Longer pause durations in speech } \\
\text { can indicate deception. }\end{array}$ & $\begin{array}{l}\text { Extroversion vs. Introversion - Extroverts } \\
\text { typically lie more than introverts; however, } \\
\text { introverts display more cues to deception. }\end{array}$ \\
\hline $\begin{array}{l}\text { Self-references - Lower use of self- } \\
\text { references (e.g. "I", "me", or "mine") and } \\
\text { higher use of group-references (e.g. "we") } \\
\text { can indicate deception. }\end{array}$ & $\begin{array}{l}\text { Talking - Individuals tend to spend less } \\
\text { time talking or give overall shorter } \\
\text { statements when being deceptive. }\end{array}$ & $\begin{array}{l}\text { Self-Monitoring - High self-monitoring (i.e. } \\
\text { controlling behavior in front of others) may } \\
\text { enable deception skills, but strong self- } \\
\text { consciousness tends to make a less believable } \\
\text { impression. }\end{array}$ \\
\hline $\begin{array}{l}\text { Immediacy cues - Failing to be direct, } \\
\text { relevant, logically-organized, and clear can } \\
\text { indicate deception. }\end{array}$ & $\begin{array}{l}\text { Repetition - Consecutively repeating a } \\
\text { phrase or word in speech can indicate } \\
\text { deception. }\end{array}$ & $\begin{array}{l}\text { Cross-Cultural Deception Detection - Cultures } \\
\text { may define deception differently and it is more } \\
\text { difficult to detection deception across cultures } \\
\text { than within a culture. }\end{array}$ \\
\hline $\begin{array}{l}\text { Lexical diversity - Failing to use a variety } \\
\text { of words in speech can indicate deception. }\end{array}$ & $\begin{array}{l}\text { Speech Errors - Speech that is non-fluent } \\
\text { or not understandable, grammatical errors, } \\
\text { sentence incompletion, slips of the tongue } \\
\text { may indicate deception. }\end{array}$ & $\begin{array}{l}\text { Language Differences - Deception detection is } \\
\text { more difficult when speaking with someone in a } \\
\text { foreign language, partly because it may } \\
\text { automatically elevate uncertainty and tension. }\end{array}$ \\
\hline
\end{tabular}


APPLYING DECEPTION DETECTION TO TRUE AND FALSE CONFESSIONS

\section{The Present Study}

This study bridges empirically-supported deception detection cues with the practice of identifying of true and false confessions. With the goal of identifying an applicable deception detection approach or valid cues to evaluate confession evidence, this study tests the efficacy of training in deception detection in the context of audio-recorded true and false confessions. Previous research applying deception detection cues to true and false confessions have only focused on verbal cues. This study seeks to test the efficacy of paralinguistic cues, which have not previously been examined in the context of confessions.

The study used an online experimental survey to evaluate the efficacy of paralingustic cues in judging veracity of true and false confessions. The survey presented a training video and subsequently presented six audio-recorded confessions - half of which were true and half false -

for participants to rate as true or false. In the interest of comparing verbal and paralinguistic cues, the survey was initially designed with two training videos and one control video. Due to expectations of a low response rate, concerns about applicability of verbal cues to confession statements, and potential difficulties in participant interpretation of verbal cues, only the paralinguistic training condition and the control condition were retained. The control training video presented general deception detection information (e.g. cultural considerations in deception detection) that were unlikely to be relevant to the stimuli (i.e. true and false confessions) (See Table 1 for control condition cues). Verbal cues were dropped from participants partially because prior studies raised concerns about reliability and difficulties in assessment (i.e. content analysis) (e.g. Porter \& Yuille, 1996, Appleby et al., 2013, Willén \& Strömwall, 2012). Further, Porter \& ten Brinke (2010)'s review of deception detection cues indicated that certain paralingustic cues are highly supported by the research, including pauses 
APPLYING DECEPTION DETECTION TO TRUE AND FALSE CONFESSIONS

and repetition, while verbal cues are more likely to require "knowledge of its proper manner of interpretation". Lastly, while prior research has examined the applicability of verbal cues to deception, the examination of relevant paralingustic cues to true and false confessions is a novel contribution by this study.

This study design is unique in using an online survey with embedded video and audio to conduct an experiment on deception detection. While previous experimental studies (e.g. Kassin et al., 2005, Vrij, Edward, \& Bull, 2001) relied on in-person meetings to administer training and collect data, this study conducts both through an online survey, which demands less time and resource investment by researchers. A secondary goal of this study was to evaluate the online experimental survey design which is able to (1) randomly assign participants into experimental and control conditions, (2) administer training and stimuli embedded in the survey, (3) recruit greater numbers of participants that may be difficult to access or recruit in person.

\section{Research Questions}

Research Question 1 (RQ1). This study evaluates if conducting online experimental studies on deception detection is an effective alternative to traditional, in-person experiments. Response rates, attribution, missing data, and time to completion data will be examined in a qualitative assessment of the methodology.

RQ2. Prior studies have found that individuals are generally poor at detecting deception or ascertaining veracity of confessions, with accuracy rates around $50 \%$ or at chance levels (Vrij, 2008a). Further this finding holds true across different professions, training, and years of experience (Aamodt \& Custer, 2006). Are accuracy rates in identifying true and false confessions are also around chance levels? It is expected that overall accuracy rates for both conditions combined will not deviate significantly from chance $(50 \%)$. 
APPLYING DECEPTION DETECTION TO TRUE AND FALSE CONFESSIONS

RQ3. Past research finds that training in deception detection increases confidence in deception detection abilities, however it appears that confidence is not actually associated with accuracy. This raises concerns investigators who receive deception detection training will be overconfident in their abilities (e.g. Kassin et al., 2005). The association between accuracy and confidence of participants in this study will be examined. It is expected that there will also be no significant correlation between confidence and accuracy. Furthermore, participants are expected to overestimate their abilities by providing ratings of confidence above the midpoint of the confidence rating scale.

RQ4. Empirically-supported paralingustic cues may increase accuracy in judging veracity of confessions. Despite the discouraging findings of many prevalent lie detection trainings or techniques, relevant training in empirically-based cues can increase accuracy rates (Vrij, 2008a). As paralingustic cues have not previously been tested with confessions, this study examines if participant receiving training in paralingustic cues will have higher accuracy in detecting true and false confessions in comparison to participants receiving a placebo training. It is hypothesized that training in paralinguistic cues will lead to a higher rate of accuracy in comparison to the control group.

RQ5. The general public demonstrates an overall increased accuracy with identifying true statements in comparison to false statements (Burgoon, Buller, Ebesu, \& Rockwell, 2009; Levine, Park, \& McCornack, 1999; Vrij \& Baxter, 1999). This question, however, has not been examined with regard to confessions. Will participants demonstrate a higher rate of accuracy in identifying true confessions relative to false confessions? It is expected that accuracy rates of identifying true confessions will be higher than accuracy rates of identifying false confessions across both groups of participants. 
APPLYING DECEPTION DETECTION TO TRUE AND FALSE CONFESSIONS

RQ6. If confidence increases as a result of training, will the control group with the placebo training also demonstrate increased confidence in judgments of veracity? Differences in confidence ratings across groups may not be demonstrated, given that the participants in the placebo condition are unaware of the irrelevance of their training to the stimuli. Alternatively, participants in control group are unlikely to find their cues to deception relevant to the stimuli, thus, they may not be less confident in their judgments.

RQ7. To test the efficacy of the trainings, the utility of specific paralingustic or placebo training cues to participants' decision-making will be examined. To this end, the frequency of cues from the trainings indicated by participants to be relevant to their judgment of a confession as true or false will assessed.

\section{Methods}

This study evaluated the effects of empirically-based video education (i.e. training) in deception detection on identification of true and false confessions and consisted of two phases.

Phase 1 consisted of participant interviews to obtain audio-recorded true and false confessions to events that elicit emotions of guilt or embarrassment. To obtain true and false confessions, the methodology from Kassin, Meissner, and Norwich's (2005) study was adapted for use in this study. The audio-recorded confessions obtained in Phase I were used as stimuli in Phase II. Phase II used an experimental survey to administer training in deception detection to participants and to subsequently present stimuli (i.e. audio-recorded confessions) to test their ability to identify true and false confessions. Phase II employed a $2 \times 2$ experimental design to test the efficacy of deception detection training in paralinguistic cues. The first independent variable (IV) manipulated was veracity (i.e. truthfulness) with two levels: truth and falseness. The second IV 
APPLYING DECEPTION DETECTION TO TRUE AND FALSE CONFESSIONS

was the deception detection training type (i.e. paralingustic vs. control). The primary dependent variables measured were the judgment of veracity (i.e. true vs. false) and level of confidence.

\section{Phase I Participants}

The participants were 11 graduate students at a major university in the Pacific Northwest who were recruited through flyer invitation from eight different departments. Phase 1 participants were required to be graduate students due to the intent to distribute the survey in Phase 2 solely to undergraduate students. In order to avoid any overlap of participants, graduate student status was a requirement for participation in Phase I and undergraduate student status was a requirement for participation in Phase II.

\section{Phase I Procedure}

Participants were asked to provide a true confession (Part A) and a false confession (Part B) by the researcher during a private interview. The confession was recorded in the form of a story told by the participant and the single prompting question by the researcher was excluded from the audio-recording. To maintain confidentiality, participants were asked to avoid using full names, specific locations, or other information that could lead to their identification. Further, participants were told that absolute confidentiality cannot be guaranteed because the audiorecordings that may be played for participants in future studies. They were asked to consider any possible negative consequences if the content of their true confession was linked to their identity. These consequences, which were delineated in a checklist on the consent form, included harm to reputation (1), psychological harm such as anxiety or depression (2), risk of loss of employment or employability (3), risk of damage to personal or professional relationships (4), criminal or civil liability or consequences (5). Audio-recorded confessions were only collected from 
participants who confirmed that none of the consequences in the checklist could result from a loss of confidentiality through identification by signing a consent to release the audio-recordings.

In Part A (i.e. true confession), participants were asked to identify a recent event or act in their past that elicited emotions of guilt or embarrassment and to provide a two to three minute confession to that event or act, providing as much detail as they deemed necessary. Once the researcher completed the instructions, the participant was given up to 5 minutes prepare to tell their true confession. Afterwards the researcher began the audio-recording and the participant provided their true confession. The true and false confessions were collected using a "yoked" procedure adapted from Kassin, Meissner, and Norwick's (2005) study. The first participant provided a true confession, then that true confession was condensed by the researcher into a short paragraph that detailed the "who, what, where, when, and why" of the confession. This short paragraph was provided in typed form to the second participant to be used as a prompt to devise a false confession. This procedure was repeated for all participants.

In Part B (i.e. false confession), each participant was instructed to imagine as if they experienced the story provided to them and to devise a two to three minute confession to that event or act, providing as much detail as they deemed necessary. Participants were given up to 5 minutes to prepare their false confession. After this time, the researcher began the audio recording and the participant provided their false confession. In compensation for their participation, each participant was awarded a $\$ 15.00$ gift certificate to a local store. The "yoked" procedure was repeated until a total of 18 confessions were obtained from participants, 9 true and 9 false. For the survey in Phase II, three true and three false confessions were randomly selected to be included in the survey. Efforts were taken to avoid selection of two confessions of the same event (i.e. a true and false confession to the same event or act by two different participants), two 
APPLYING DECEPTION DETECTION TO TRUE AND FALSE CONFESSIONS

confessions by the same individual (i.e. a true and false confession provided by the same participant), and confessions whose audio-recording was compromised (e.g. background noise).

\section{Phase II Participants}

Participants were 63 undergraduate students at a major university in the Pacific Northwest. 60 participants provided full demographical information. Considering the undergraduate sample, age was relatively well-represented: $44.8 \%(n=26)$ of participants were $18-21,25.9 \%(n=15)$ were $22-25,6.9 \%(n=4)$ were $26-29,15.5 \%(n=9)$ were $30-39$, and $6.9 \%(n=4)$ were $40-59.69 .0 \%(n=40)$ of participants identified as female, $29.3 \%(n=17)$ identified as male, and $1.7 \%(n=1)$ participants identified as 'other'. $67.2 \%(n=39)$ of the sample identified as White or European American, $8.6 \%(n=5)$ identified as Asian, $6.9 \%(n=4)$ identified as Black or African American, 2.7\% $(n=1)$ identified as Native American/Native Alaskan, $10.3 \%(n=6)$ identified their race as 'other', and 5.1\% $(n=3)$ identified with more than one race category. Within the sample, 5.2\% $(n=3)$ of participants identified their ethnicity as Hispanic, $72.4 \%(n=42)$ identified as White/Non-Hispanic, and 22.4\% $(n=13)$ identified their ethnicity as 'other'. This sample was considered to be representative of the demographics the institution's population.

\section{Phase II Experimental Procedure}

The experimental survey was administered online through Qualtrics software to participants, who were randomly assigned to the experimental group or the control group by the software. The deception detection trainings were delivered by video and embedded in the survey from publicdomain YouTube videos. All video trainings used in the experiment were obtained through Dr. Norah Dunbar's course on deception detection from the University of Oklahoma (Janux, 2014). In each video, Dr. Dunbar, a researcher in communication and deception detection, presented 
APPLYING DECEPTION DETECTION TO TRUE AND FALSE CONFESSIONS

training on deception detection and covered the following studies: DePaulo et al., (2003), Feeley and De Turck (1998), Mann, Vrij, Leal, Warmelink, and Forrester (2012), and Vrij (2008a).

The experimental group received a training video on paralingustic cues to deception, while the control group received a placebo video that provided general deception detection information such as personality influences and cross-cultural differences. None of the cues covered in the placebo training video were referenced in any confession obtained in Phase I. The placebo training primed a participant for deception detection without providing any cues to deception that were relevant to the confessions. DePaulo, Lassiter, and Stone (1982) indicate that priming for deception detection has an effect on deception detection accuracy even when only instructing participants to focus on certain cues. Using a placebo training condition instead of a "no training" condition provided a closer match between the two groups in order to allow for the effect of paralinguistic training to be detected, rather than an effect of any training that primes a participant to detect deception.

From the paralingustic and placebo videos, five of the most salient deception cues covered in the video were summarized below the video for the participants. The deception detection cues and their summaries are shown in Table 1 by training type. Participants were asked to think about these cues when completing the audio-recordings. Due to different quantities of applicable cues from each video, certain cues were added from the research literature to the text below the video in order to compose five cues for each group. However, the broad goal of this study was to test the applicability of paralinguistic cues to confessions, rather than the efficacy of the specific cues presented. 
APPLYING DECEPTION DETECTION TO TRUE AND FALSE CONFESSIONS

\section{Phase II Measures}

After the videos, the six audio-recorded confessions were provided as stimuli for participants to judge as 'true' or 'false'. Each confession was presented on a separate webpage with a set of questions regarding judgment of veracity, confidence level, and specific cues considered in judgment. Participants were prevented from returning to already submitted webpages. No feedback regarding accuracy was given at any point during or after the survey.

Judgment of veracity was obtained using a dichotomous rating of either 'true' or 'false'. The confidence in judgment rating was obtained using a six-point Likert scale ranging from 0 (not at all confident) to 5 (completely confident) with a midpoint of 2.5. Information on the specific cues from the video considered by participants in their judgment of the confession was obtained through a multiple selection question for the five cues from the corresponding video with an open-answer "other" option. This question allowed the participant to indicate which of the cues, if any, they noticed or used to judge a specific confession. The open-answer "other" option collected any alternative information that the participants considered in judging veracity.

Demographic information regarding age, gender, race \& ethnicity, and student status was collected at the end of the survey. A final question assessed any technical issues that may have been experienced by the participant. Technical issues did not appear to be an issue for participants with only one participant indicating difficulty with listening to a single recording. The final page of the survey consisted of a thank you notification, an explanation of the lottery entry process, and contact information for the researchers. The survey software, Qualtrics, collected time information for each participant regarding how many seconds/minutes were spent on a given page of the survey. 
APPLYING DECEPTION DETECTION TO TRUE AND FALSE CONFESSIONS

\section{Results}

Research Question 1 evaluated the efficacy of conducting an online experimental survey on deception detection in comparison to traditional, in-person experiments. Distribution resulted in an estimated $19 \%$ response rate (i.e. opening survey) and a $7.6 \%$ completion rate. Survey time information obtained through Qualtrics was used to exclude participants falling below the minimum time required to complete each training video and audio-recording.

Sixty-three valid surveys were analyzed out of 159 total (i.e. complete and incomplete) surveys collected. During data collection, 159 individual survey results were collected. Note that Qualtrics software submits incomplete surveys after one week of inactivity. A survey time variable was calculated to assess minutes spent within the survey by each participant using indicators of date/time begun and date/time of last activity. Thirty-five surveys were excluded due to no time spent on survey. Five surveys were excluded due to participants indicating their student status as not undergraduate. Qualtrics allows the addition of timing questions on each survey page that can indicate the time (in seconds) that a participant spends on a given page before submitting the page and continuing onto the next. These timing variables allowed the assessment of how long a participant spent on the video page and on each confession page in order to fully watch the video and fully listen to each audio-recording. The minimum required time to complete the activities was estimated to be 20 minutes. Forty-five surveys were excluded due to total survey time falling below 20 minutes. Note that these 45 surveys included incomplete surveys that contained no data. Eleven surveys were excluded because survey time exceeded three hours, which raised concerns about the effectiveness of the training after a significant period of time. Note that the majority of the surveys falling over the acceptable time 
were also incompletes where participants left the survey at some point but did not close out of the browser until the following day or days later.

Research Question 2 examined the overall accuracy of participants in comparison to chance levels of accuracy. The overall accuracy rate of participants was $52.9 \%(n=63)$, which did not differ significantly from chance levels, $t(62)=1.12, p=\mathrm{N} . \mathrm{S}, \mathrm{d}=.141$. Accuracy rates per each of the six confessions ranged from $36.1 \%$ to $71.7 \%$, indicating variability in accuracy rates across each individual confession (See Table 2).

Table 2

Accuracy Rates and Mean Confidence Across Confessions

\begin{tabular}{lcccc}
\hline & $N$ & Accuracy \% & $\begin{array}{c}\text { Mean } \\
\text { Confidence }\end{array}$ & $\begin{array}{c}\text { SD } \\
\text { Confidence }\end{array}$ \\
\hline True Confession \#1 & 60 & 60.0 & 3.38 & 1.34 \\
True Confession \#2 & 60 & 71.7 & 3.50 & 1.48 \\
True Confession \#3 & 61 & 36.1 & 3.16 & 1.07 \\
False Confession \#1 & 62 & 58.1 & 3.40 & 1.37 \\
False Confession \#2 & 61 & 47.5 & 2.95 & 1.42 \\
False Confession \#3 & 59 & 42.4 & 3.21 & 1.41 \\
All True Confessions & 62 & 55.7 & 3.35 & 1.01 \\
All False & 63 & 50.3 & 3.19 & 1.06 \\
Confessions & $\mathbf{6 3}$ & $\mathbf{5 2 . 9}$ & $\mathbf{3 . 2 7}$ & $\mathbf{0 . 9 5}$ \\
\hline All Confessions &
\end{tabular}

Note: Confidence was scaled from $0-5$, with a midpoint of 2.5

Research Question 3 examined the association between participants' accuracy in identifying true and false confessions and their confidence level in the judgment. Correlational analyses showed that the overall accuracy rate and mean confidence across all confessions were not significantly correlated $(r=.027, p=\mathrm{N}$.S $)$. Confidence in true confession judgments was not significantly correlated to accuracy in judging true confessions $(r=.145, p=\mathrm{N} . \mathrm{S})$ and confidence in false confession judgments was not significantly correlated to accuracy in judging false confessions $(r=(-) .089, p=$ N.S $)$. Despite the nonsignificant findings, the correlational coefficient of confidence in true confessions is positive and slightly higher than the coefficient of 
confidence in false confessions. The confidence rating scale ranged from 0 (not at all confident) to 5 (completely confident) with a midpoint of 2.5 . The average rating of confidence for true confessions $(M=3.35, S D=1.01)$ was slightly higher than the average rating of confidence for false confessions $(M=3.19, S D=1.06)$, with an overall average rating of confidence of 3.27 ( $S D$ $=0.95)($ See Table 2$)$. Both groups had mean confidence levels above the scale mid-point of 2.5 (See Figure 2).

Research Question 4 examined if training in paralingustic cues would increase accuracy in identifying true and false confessions in comparison to a placebo training. An independentsamples $t$-test was conducted to examine differences in accuracy between the paralingustic training group and the control group. The results indicated that the mean accuracy rate of the paralingustic group $(M=.553, S D=.202)$ was higher than mean accuracy rate of the control group $(M=.508, S D=.210)$, however the difference was not found to be statistically significant $t(61)=.870, p=\mathrm{N} . \mathrm{S}, d=.22$. Figure 1 displays the means accuracy rates for confessions by condition. 
Figure 1: Accuracy Rates in Identifying Confessions By Group

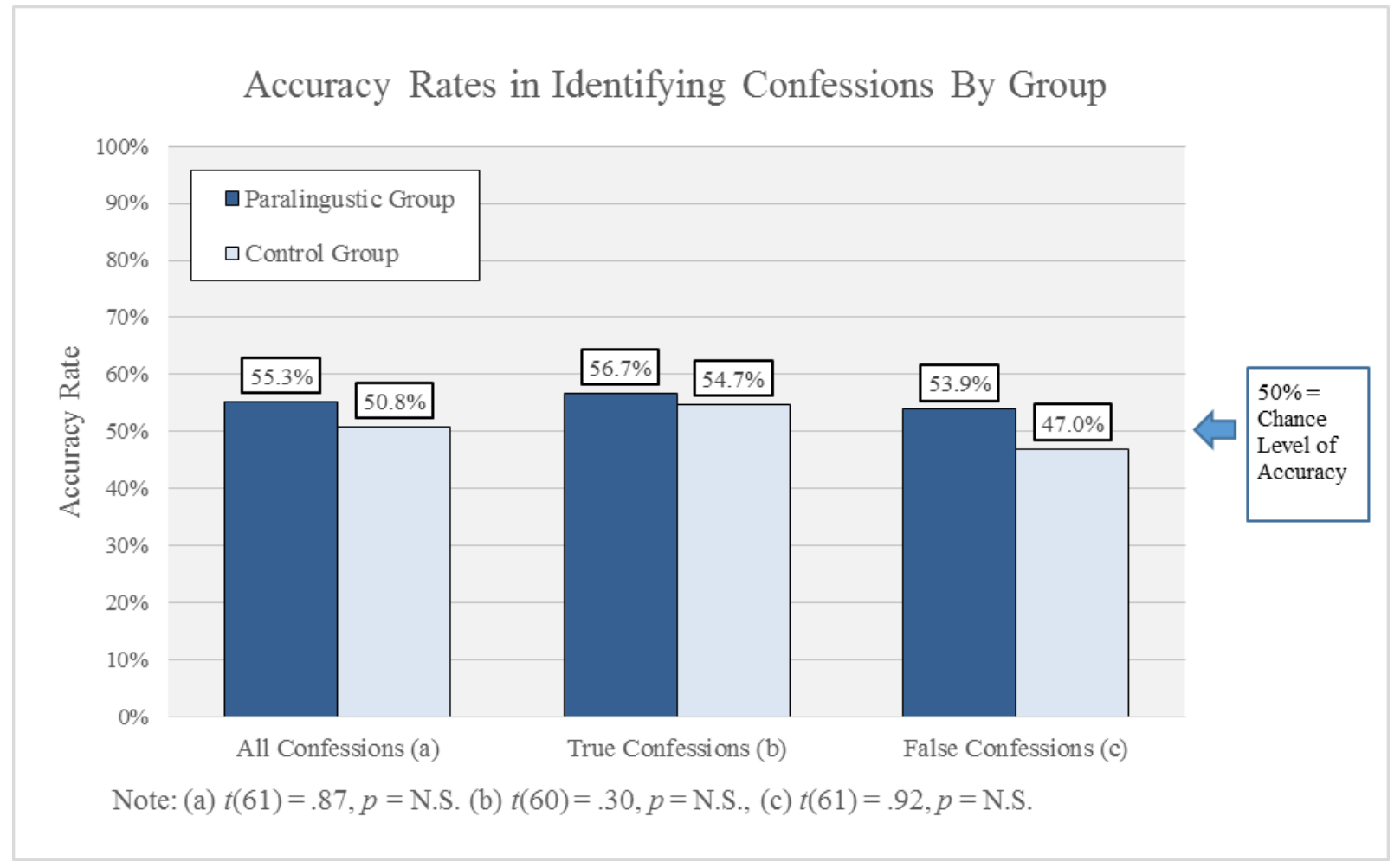

Research Question 5 compared accuracy rates between true and false confessions for all participants combined in order to test for the presence of a truth bias in the sample. A truth bias would be indicated by significantly higher accuracy for true confessions in comparison to false confessions. The accuracy rate of true confessions was $55.7 \%(n=62)$ and the accuracy rate of identifying false confessions was $50.3 \%(n=63)$. A paired-samples $t$-test was conducted to evaluate if accuracy rates differed between true and false confessions. Although the accuracy rate of true confessions $(M=.557, S D=258)$ was higher than the accuracy rate for false confessions $(M=.503, S D=.300)$, this difference was not significant $t(62)=1.131, p=$ N.S., $d=.14$.

Research Question 6 examined differences between the paralingustic and control groups in terms of confidence in judgment. An independent-samples $t$-test was conducted to examine differences in confidence level. The results indicated that the mean confidence rating of the 
paralingustic group $(M=3.52, S D=.184)$ was significantly higher than mean confidence rating of the control group $(M=3.05, S D=.149), t(61)=2.017, p=.048, d=0.51$ (See Figure 2).

Figure 2. Mean Confidence Level in Judgment of True and False Confessions By group

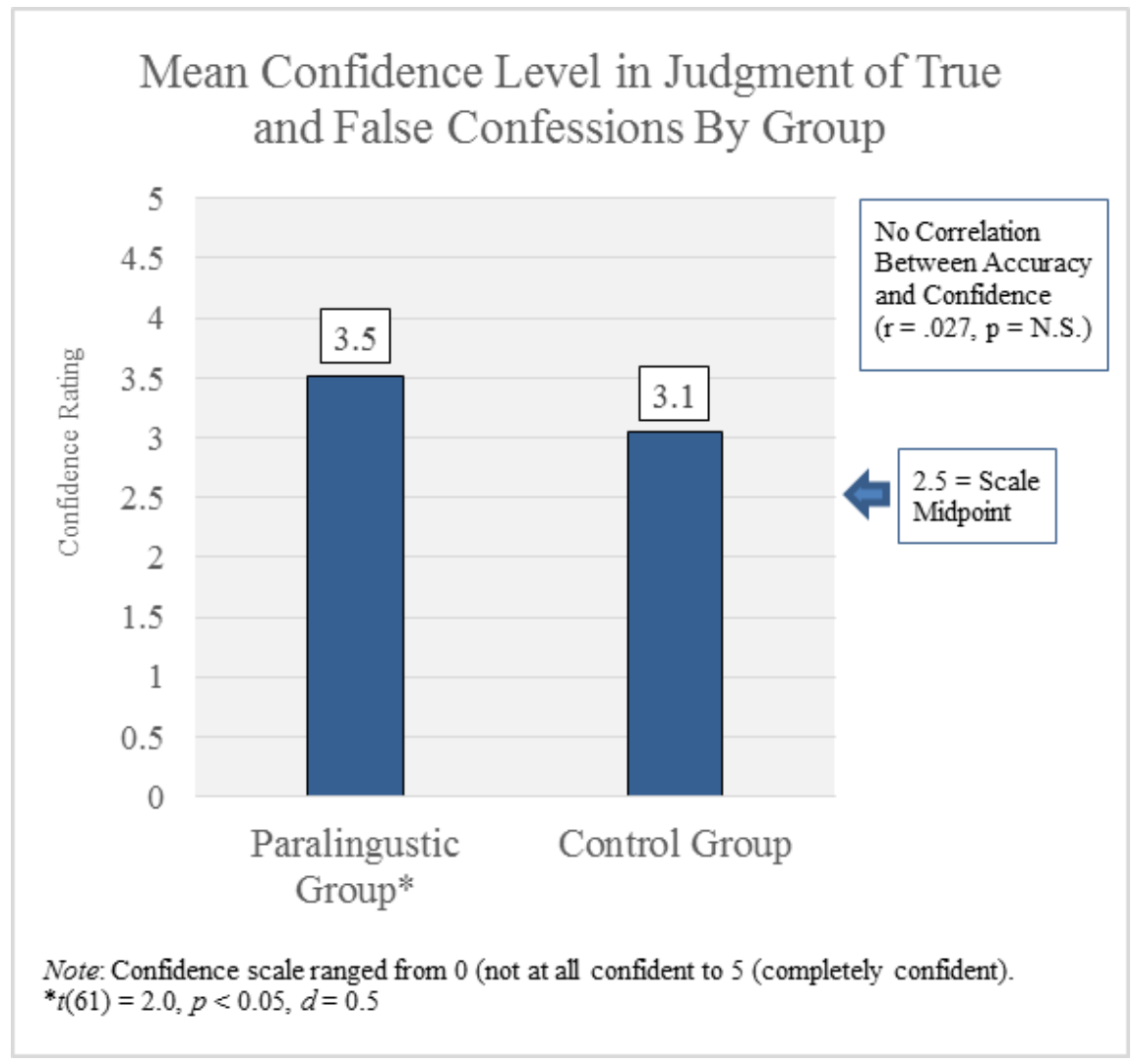

Finally, Research Question 7 tested the manipulation effect of the experiment by examining the frequency of cues from the training videos that were indicated as relevant to participants' judgments. Participants in each condition indicated which cues, if any, from their training video were used in judging veracity, with an option to write-in other cues (see Table 3 for frequency of cues used by group type). The frequency counts indicate that the paralingustic group $(f=304)$ indicated a greater number of cues relevant to their judgment in comparison to the control group $(f=129)$. 
Table 3

Frequency of Cues Used By Participant Group

\begin{tabular}{|c|c|c|c|c|c|}
\hline Paralingustic Group & $f$ & $\%$ & Control Group & $f$ & $\%$ \\
\hline Longer Pause Durations & 75 & $22.3 \%$ & High Self-Monitoring & 58 & $45.0 \%$ \\
\hline Speech Errors & 69 & $20.5 \%$ & $\begin{array}{l}\text { Extroversion vs. } \\
\text { Introversion }\end{array}$ & 46 & $35.7 \%$ \\
\hline High Pitch & 62 & $18.5 \%$ & $\begin{array}{l}\text { Presence of Personality } \\
\text { Disorder }\end{array}$ & 12 & $9.3 \%$ \\
\hline Phrase/Word Repetition & 58 & $17.3 \%$ & $\begin{array}{l}\text { Cross-Cultural } \\
\text { Differences }\end{array}$ & 7 & $5.4 \%$ \\
\hline Speech Time & 40 & $11.9 \%$ & Language Differences & 6 & $4.7 \%$ \\
\hline All Paralingustic Cues & 304 & $100.0 \%$ & All Control Cues & 129 & $100.0 \%$ \\
\hline
\end{tabular}

Participants also provided qualitative information using the open-text answer underneath the 'other' option on the multiple answer question regarding specific cues considered relevant to their judgment. No character length limited the answers and some were extensive (e.g. "she had heavier breathing and small sighs in the pauses making it seem as though she was telling a lie or was struggling to make a story"). Participant were able to indicate cues of their own, rather than choosing cues from their training, such as "changes in tone" or "upspeak" from participants in the paralingustic trainings. For example, one participant in the placebo training wrote in "lack of empathy" for a judgment of deception. Most commonly, however, participants in the paralingustic confessions wrote in cues that matched their training such as "ums", "speech hesitation", "sights, ums", “use of ums, ahs", “a lot of hesitation noises”, "speech hesitation”, "lots of 'um”, “um's and uh's”, “semi-frequent 'uhm's' and 'uh's'”, “said 'um' numerous times", "hesitation ("ums" \& "uhs")", “some phrases jumbled together”, “too many 'ums’", “[quiet] talk, mumbling", "voice inflection", and "pausing”. Conversely, some participants in the paralingustic training mentioned verbal cues, such as "inconsistencies in story", "less plausible story", "this is implausible", and "lack of specificity". These responses indicated that participants used the open-text options mostly to elaborate on or reaffirm their choices out of the cues 
APPLYING DECEPTION DETECTION TO TRUE AND FALSE CONFESSIONS

provided through their training, but a few participants mentioned cues outside of their training as relevant to their judgment.

\section{Discussion}

This study tested whether training in paralingustic cues to deception increased accuracy in identifying true and false confessions, the association between confidence in judgment and accuracy, and the efficacy of a conducting experiments on deception detection online. Consistent with prior research on deception detection, the combined accuracy rate of all participants was not significantly different from chance levels and confidence was not found to be related to accuracy - either positively or negatively (Research Questions 2 and 3). Deception detection accuracy on true and false statements tends to be around chance levels regardless of law enforcement experience or confidence (Aamodt \& Custer, 2006). With respect to true and false confessions specifically, confidence has also been indicated to be unrelated to accuracy (Kassin et al., 2005).

Contrary to expectation, there were no significant difference in the accuracy rates of the paralingustic and control groups (Research Question 4). Despite the observed non-zero effect size (i.e 0.22 ) of training on the accuracy of the paralingustic group, the mean difference between the groups was not statistically significant. These results do not indicate that all paralingustic cues are ineffective in identifying true or false confessions, rather that the training using this particular set of paralingustic cues is not suggested to be effective in identifying these true and false confessions.

Prior research had not considered the applicability of paralingustic deception detection cues to true and false confession; instead, the few studies testing the applicability of deception detection cues to confessions focused on verbal cues. Verbal deception detection cues have also, on the whole, not been applicable to true and false confessions to the same extent as to true and 
APPLYING DECEPTION DETECTION TO TRUE AND FALSE CONFESSIONS

false exculpatory statements. This was indicated in Appleby et al.'s (2013) and Garrett's (2010) content analyses of false confessions, which found extensive visual and auditory details in false confessions, although paucity of such detail is a cue to deception in false exculpatory statements (Bond \& DePaulo, 2008; Vrij, 2008a). Moreover, Willén \& Strömwall (2012) found that two empirically-tested measures of verbal cues to deception (i.e. Statement Validity Analysis, Reality Monitoring) did not distinguish between true and false confessions and only a minor subset of the individual cues were able to do so. Vrij's (2008) meta-analysis, failed to provide strong support for these individual cues indicated in Willén \& Strömwall's (2012) study to effectively distinguish between true and false confessions. This meta-analysis, however, examined studies that had tested all types of true and false statements, not just confessions. Overall, research has been encouraging in the efficacy of empirically-supported paralingustic and verbal cues to deception in identifying true and false statements (Vrij, 2008a; Vrij, Edward, \& Bull, 2001). The findings of the present study and studies examining verbal deception detection cues in confessions suggest that deception detection cues indicated as effective in identifying true and false statements may have a differential relationship to true and false confessions.

Interestingly, participants did not show a higher rate of accuracy in identifying true confessions in comparison to false confessions (Research Question 5), contrary to expectations. Despite a small, non-zero effect size (0.14) of type of statement (true vs. false) on accuracy rates, the difference between accuracy of identifying true and false confessions was not statistically significant. This lack of truth bias, demonstrated by participants in this study differs from prior research on participants' judgments of true and false statements. Investigators tend to have a "guilt bias" - an increased likelihood of judging both true confessions and false confessions as true and the suspect as guilty (Kassin et al., 2005; Burgoon et al., 2009). Participants who are not 
APPLYING DECEPTION DETECTION TO TRUE AND FALSE CONFESSIONS

trained investigators, however, demonstrate a 'truth bias' and, thus, are more likely to judge true statements as true than false statements as false (Levine et al., 1999; Vrij \& Baxter, 1999). The findings of the present study suggest that the "truth bias" may not be demonstrated when identifying true and false confessions. As confessions may qualitatively differ from the types of statements (e.g. exculpatory statements, social conversation) used in prior deception detection research (e.g. Kassin et al., 2003, Anderson et al., 1999), participants may assess confessions differently than other types of statements.

Confidence in judgment of true and false confessions was not found to be significantly related to accuracy of identifying true and false confessions, although participants across both groups demonstrated levels of confidence above the scale midpoint. Moreover, participants in the paralingustic group indicated significantly higher confidence than participants in the control group (Research Question 6). The finding that confidence increases but accuracy does not increase due to training highlights a concerning trend in deception detection research. With specific regard to confessions, trained investigators also demonstrate poor accuracy and increased confidence. In the study which provided the methodology for obtaining true and false confessions for the present study, Kassin et al. (2005) found that trained investigators were less accurate at identifying true and false confessions in comparison to untrained students, but they were more confident in their judgments. Trained investigators were not only overconfident in their abilities, but they also displayed a "guilt bias" which resulted in an increased perception of both true and false confessions as true. Prior research has generally indicated that trained investigators, in comparison to untrained participants, indicate higher confidence in deception detection abilities while not displaying higher rates of accuracy (Meissner \& Kassin, 2004). The 
APPLYING DECEPTION DETECTION TO TRUE AND FALSE CONFESSIONS

implications of this discrepancy between confidence and deception detection ability will be later discussed.

Confidence may have been increased for the paralingustic group because participants in the control group did not find their cues to deception relevant to the same extent as participants in the paralingustic group, and thus were less confident in their judgments. This is supported by the difference in frequency of cues indicated as relevant to judgment between the groups. Participants in the paralingustic group indicated a higher frequency of cues from their training as relevant to their judgments. This may suggest that the paralingustic training was more useful to the decision-making of participants than the control training (Research Question 7). However, it is important to note that the control condition was a placebo training and the participants had no knowledge that their training would be inapplicable to the confessions. Cues of the placebo training such as self-monitoring or extroversion vs. introversion, which were the most frequently indicated by participants, could have been construed by participants to be present in the confession. None of the placebo cues were explicitly mentioned or alluded to in the confessions, however participants were not prevented from attributing qualities to the individual telling confession based on the content of the confession.

Conducting online experimental studies appears to be resource-effective, with less effort required in soliciting participants and minimal researcher investment (Research Question 1). The response rate of the survey in the present study was low. Low response rates tend to increase the likelihood that a sample is not representative of the population examined, which decreases the external validity of the findings. The low completion rate suggests there may be a trade-off between lower researcher investment and a lower participation rate. Fewer participants may be recruited online than in person. However, a researcher may conduct multiple distributions to 
APPLYING DECEPTION DETECTION TO TRUE AND FALSE CONFESSIONS

multiple participant pools, resulting in more solicitation than may otherwise be possible through in-person recruitment. Experimental studies may reach more extensive participant pools through venues like Mechanical Turk, which provides more diverse participants than typical college samples (Buhrmester, Kwang, \& Gosling, 2011). Like in-person experiments, an online survey can eliminate invalid participation through collected time information and can obtain qualitative feedback.

\section{Implications}

The results of this study regarding poor judgment accuracy and increased confidence due to training have serious implications for interrogational practices and assessment of confessions provided by suspects. Training in deception detection, especially if it appears scientifically-based and objective, appears to increase confidence in deception detection ability, regardless of actual increases in deception detection ability. Trained investigators who are confident in their ability to detect deception appear to be poorer in their ability to detect true and false exculpatory statements (i.e. denials), being more likely to perceive denials provided by suspects as deceptive (Meissner \& Kassin, 2002). Training in deception detection cues that are not empiricallysupported may be to blame for the poor accuracy of trained investigators. For instance, the Reid technique increases the confidence of trained individuals in their judgments of true and false exculpatory statements, however it does not increase accuracy in identification of true and false statements with both students and trained investigators (Kassin \& Fong, 1999; Meissner \& Kassin, 2002).

The "guilt bias" and unfounded confidence in deception detection ability is detrimental to the identification of innocent suspects because higher confidence is associated with increasing use of interrogational practices that may elicit false confessions. The increase in confidence of 
APPLYING DECEPTION DETECTION TO TRUE AND FALSE CONFESSIONS

investigators is also associated with an inclination to presume the guilt of a suspect, and investigators may fall prey to the confirmation bias during interrogation, which leads investigators to selectively seek and perceive new information in ways that support their belief of guilt (Kassin \& Gudjonsson, 2004). The confirmation bias was demonstrated in Kassin et al.'s (2007) experiment which found that investigators' special training in interrogation and greater confidence in their own deception detection skills lead them to presume guilt and to more frequently use psychological manipulation and confrontational techniques when interrogating suspects. Investigators who expected a suspect to be guilty perceived plausible denials as resistance to the interrogation and evidence of guilt. Investigators who expected a suspect to be innocent, in turn, perceived denials as more plausible. When confidence in deception detection ability is paired with a poor ability to actually detect deception, interrogators may assume assuredly that their interrogation will oust the guilty but they fail to identify when an innocent suspect provides a false confession.

The present study contributed to research on true and false confessions in several ways. First, the experimental design of the study demonstrated that empirically-supported deception detection training increases confidence in deception detection ability in a sample that was previously untrained in deception detection. This differs from prior research that had used experienced investigators who were possibly trained in multiple or empirically-unsupported deception detection techniques (e.g. Kassin et al., 2005). Second, it questions the applicability of paralingustic deception detection cues to confession statements, which had not previously been tested. Although paralingustic or auditory cues to deception appear to be more effective in identifying true and false statements (Anderson et al., 1999; DePaulo, Lassiter, \& Stone, 1982), this study found that training in paralingustic cues did not contribute to significantly higher rates 
APPLYING DECEPTION DETECTION TO TRUE AND FALSE CONFESSIONS

of accuracy of identifying true and false confessions. Finally, this study examined a new method to conduct experiments on deception detection by designing an experimental survey to distribute to participants online. A qualitative evaluation of this method suggests that it has the potential to minimize researchers' invested time and effort, however, additional research is needed to determine the feasibility of different research questions or the ability to obtain a desired sample size.

Thus, future researchers are encouraged to test this methodology to determine if online experimental surveys can be comparable to traditional, in-person experiments. It is important to design experimental studies with trainings to present empirically-supported cues to deception and approaches that are consistent with research on interrogation techniques. It is a possibility that online experimental studies on deception detection may be more effective for certain research questions that may not have as many limitations as the present study had. For instance, evaluating the effects of gender or mood on perceived veracity of true and false statements may be more feasible for online experimental surveys than testing the efficacy of a training in deception detection.

Additional research is needed on the applicability of paralingustic cues to confession statements, which can examine different paralingustic cues, the effects of a different training design, or the utility of paralingustic cues in distinguishing between true and false criminal confessions. The present study used confessions to non-criminal events or actions. Alternatively, future studies may explore additional applications of deception detection cues to confessions, such as verbal or nonverbal cues, and combinations of different cues. Identifying other types of false statements such as false witness statements is another direction in which future research on deception detection may contribute to the prevention of false convictions. The importance of this 
APPLYING DECEPTION DETECTION TO TRUE AND FALSE CONFESSIONS

direction is emphasized by Wilson (2003), who found that wrongful convictions may be caused partly by testimony of "smooth and convincing" liars as witnesses.

\section{Limitations}

This study faced several limitations. In terms of the methodology to elicit true and false confessions, there was a lack of corroborative evidence for the true confessions. Participants were asked to provide a true confession to an event that elicited feelings or guilt of embarrassment, however, no verification was conducted to ensure that their confessions were true. False confessions, on the other hand, were known to be false as the material for the confession was provided to participants during the procedure.

The experimental and control groups each had 30 and 32 participants, respectively. The low sample size may have contributed to a lower likelihood of differences in accuracy rates between the groups from being detected. Regarding differences in accuracy rates between the paralingustic and control groups, it is important to note that sample size $(\mathrm{N}=63)$ may have fallen short of estimated required sample size to achieve adequate statistical power. Post-hoc power analyses using the G*Power computer program (Faul \& Erdfelder, 1998) confirmed that the

study was underpowered with achieved power of 0.14. A total sample of approximately 210 participants would be needed to obtain statistical power at the recommended .80 level (Cohen, 1988) assuming a large effect size of .5. A medium effect size (0.5) was detected for the difference in mean confidence levels between the groups, however, it is inconclusive if the nonsignificant effect size of mean differences in accuracy rates $(0.22)$ between the paralingustic and control groups would hold up in future studies.

Further, the experimental training video on paralingustic cues may have been too brief to be effective. As Frank and Feeley (2003) indicate, an effective training in lie detection needs to 
APPLYING DECEPTION DETECTION TO TRUE AND FALSE CONFESSIONS

include the following elements: relevance, high stakes, proper implementation, empirical testing, generalizability across contexts, and generalizability over time. The training videos offered no exercises to test deception detection with feedback on performance. Receiving feedback on performance may have allowed participants to learn from their mistakes, but may have confounded the assessment of confidence in judgment for participants. Further, feedback on performance is not provided when deception detection is required in the real world where practitioners must often rely on only their own judgment.

Another possible limitation is the external validity of participants' assessment of confessions as stimuli. The participants were not able to interact with the individuals providing the confession or ask follow-up questions, which is possible for investigators in interrogation. However, research has found that degree of interaction may affect accuracy of identifying true and false statements in interrogation. Dunbar, Ramirez, and Burgoon (2003) suggest that the very act of interaction in the interrogational context may create an amplifying effect in terms of a deception bias in perception of veracity because observers, as opposed to individuals engaged in the conversation, tend to have higher rates of accuracy in detecting false statements but may be impaired in identifying true statements. Other research (e.g. Buller et al., 1991, Feeley \& deTurck, 1997) has indicated that observers are better at judging accuracy of a conversation than those participating in a conversation. However, most of these studies were conducted with student participants, who are likely to be unfamiliar with interrogational practice and may be more impaired or distracted by being involved in the conversation. In a study using police officers as participants, Hartwig, Granhag, Strömwall, \& Vrij (2005) found no difference in lie detection accuracy between interrogators and observers, indicating that this distinction may not be relevant to the interrogational context. 
APPLYING DECEPTION DETECTION TO TRUE AND FALSE CONFESSIONS

External validity is also a consideration because multiple modes of cues may considered in evaluating veracity in actual assessment. Verbal cues have been found to be empiricallysupported indicators of deception (Vrij, 2008a) and it is likely that practitioners rely on paralingustic cues in conjunction with verbal and nonverbal cues when judging veracity. Lastly, it is important to note that the type of deception investigated by deception detection researchers may not be generalizable to the typical case of false confessions, where the false confessor may not be motivated to get the interviewer to believe them wholeheartedly, but rather to satisfy an interviewer who is already convinced of their guilt.

\section{Conclusion}

Identification of true and false confessions is a new area of deception detection and few studies have examined which cues are associated with veracity. Nevertheless, deception detection approaches hold promise for providing empirically-supported methods of identifying false confessions in order to prevent false convictions and to avoid high costs to unjustly convicted individuals and their communities. This study suggests while certain findings from the deception detection field, such as increased confidence due to training, may hold true for confessions, paralingustic cues may be less applicable to confessions than to other types of statements. The method of distributing experimental surveys online to participants is suggested as an alternative, cost-effective method for conducting experiments on deception detection. Although deception detection research has only recently begun examining true and false confessions, there is hope for the development of empirically-based assessment of confession evidence which, in combination with knowledge on individual and situational risk factors for false confessions, can help prevent false convictions. 
APPLYING DECEPTION DETECTION TO TRUE AND FALSE CONFESSIONS

\section{Acknowledgements}

I am grateful to my adviser, Dr. Kris Henning, without whom this project would not have been possible. Thank you for your advice, support, patience, and guidance during this study! I want to thank the graduate students from the Criminology \& Criminal Justice Department and the Psychology Department for valuable feedback. Finally, my gratitude to the Honors Program for their support and financial assistance with this project. 
APPLYING DECEPTION DETECTION TO TRUE AND FALSE CONFESSIONS

\section{References}

Aamodt, M. G. \& Custer, H. (2006). Who can best catch a liar? A meta-analysis of individual differences in detecting deception. Forensic Examiner, 15(1), 6-11.

Akehurst, L., Köhnken, G., Vrij, A., \& Bull, R. (1997). Lay persons' and police officers' beliefs regarding deceptive behaviour. Applied Cognitive Psychology, 10, 461-471.

Anderson, D. E., DePaulo, B. M., Ansfield, M. E., Tickle, J. J., \& Green, E. (1999). Beliefs about cues to deception: Mindless Stereotypes or Untapped Wisdom? Journal of Nonverbal Behavior, 23(1), 67-89.

Appleby, S. C., Hasel, L. E., \& Kassin, S. M. (2013). Police-induced confessions: An empirical analysis of their content and impact. Psychology, Crime \& Law, 19(2), 111-128.

Bartol, C. \& Bartol, A. (2015). Introduction to forensic psychology: Research and application. Thousand Oaks, California: SAGE Publications, Inc.

Bedau, H. A., \& Radelet, M. L. (1987). Miscarriages of justice in potentially capital cases. Stanford Law Review, 21-179.

Bem, D. J. (1966). Inducing belief in false confessions. Journal of Personality and Social Psychology, 3, 707-710.

Blandón-Gitlin, I., Fenn, E., Masip, J., \& Yoo, A. H. (2014). Cognitive-load approaches to detect deception: Searching for cognitive mechanisms. Trends in Cognitive Sciences, 18(9), $441-444$.

Bond, C. F. \& DePaulo, B. M. (2006). Accuracy of Deception Judgments. Personality and Social Psychology Review, 10 (3), 214-234.

Bond, C. F. \& DePaulo, B. A. (2008). Individual differences in judging deception: Accuracy and Bias. Psychological Bulletin, 134(4), 477-492. Doi: 10.1037/0033-2909.134.4.477 
APPLYING DECEPTION DETECTION TO TRUE AND FALSE CONFESSIONS

Borchard, E. M. (1932). The unrecognized government in American courts. American Journal of International Law, 26(2), 261-271.

Brehm, J. W., \& Cohen, A. R. (1962). Explorations in cognitive dissonance. New York: Wiley.

Buhrmester, M., Kwang, T., \& Gosling, S. D. (2011). Amazon's Mechanical Turk a new source of inexpensive, yet high-quality, data? Perspectives on psychological science, 6(1), 3-5.

Buller, D. B. \& Burgoon, J. K. (1996). Interpersonal deception theory. Communication Theory, 6(3), 203-242.

Buller, D. B., Strzyzewski, K. D., \& Hunsaker, F. G. (1991). Interpersonal deception: II. The inferiority of conversational partners as deception detectors. Communication Monographs, 58, 25-40.

Burgoon, J. K., Buller, D. B., Ebesu, A. S., Rockwell, P. (1994) Interpersonal deception v. accuracy in deception detection. Communication Monographs, 61(4), 303-325.

Burgoon, J. K. \& Newton, D. A. (1991). Applying a social meaning model to relational message interpretations of conversational involvement: Comparing observer and participant perspectives. Southern Journal of Communication, 56(2), 96-113.

Burgoon, J. K., \& Qin, T. (2006). The dynamic nature of deceptive verbal communication. Journal of Language and Social Psychology, 25(1), 76-96.

Cohen, J. (1992). A power primer. Psychological Bulletin, 112(1), 155-159.

Davis, M., Markus, K. A., Walters, S. B., Vorus, N., \& Conners, B. (2005). Behavioral cues to deception vs. topic incriminating potential in criminal confessions. Law and Human Behavior, 29(6), 683-704. 
APPLYING DECEPTION DETECTION TO TRUE AND FALSE CONFESSIONS

DePaulo, B. M., \& Kirkendol, S. E. (1989). The motivational impairment effect in the communication of deception. In J. C. Yuille (Ed.), Credibility assessment (pp. 51-70). Dordrecht, the Netherlands: Kluwer.

DePaulo, B. M., Lassiter, G. D., \& Stone, J. I. (1982) Attentional determinants of success at detecting deception and truth. Personality and Social Psychology Bulletin, 8(2), 273-279.

DePaulo, B. M., Lindsay, J. J., Malone, B. E., Muhlenbruck, L., Charlton, K. \& Cooper, H. (2003). Cues to deception. Psychological Bulletin, 129(1), 74-118.

DePaulo, B. M. \& Pfeifer, R. L. (1986). On-the-job experience and skill at detecting deception. Journal of Applied Social Psychology, 16(3), 249-267.

DePaulo, B., Rosenthal, R., Rieder-Green, C., \& Rosenkrantz, J. (1982). Diagnosing deceptive and mixed messages from verbal and nonverbal cues. Journal of Experimental Social Psychology, 18(5), 433-446.

Dunbar, N.E., Ramirez, A., Burgoon, J. K. (2003). The effects of participation on the ability to judge deceit. Communication Reports, 16(1), 23-33.

Drizin, S. A., \& Colgan, B. A. (2004). Tales from the juvenile confession front. In Interrogations, confessions, and entrapment (pp. 127-162). Springer US.

Drizin, S. A., \& Leo, R. A. (2004). The problem of false confessions in the post-DNA world. North Carolina Law Review, 82, 891-1007.

Ekman, P., \& Friesen, W. V. (1969). The repertoire of nonverbal behavior: Categories, origins, usage, and coding. Semiotica, 1(1), 49-98.

Ekman, P., \& Friesen, W. V. (1974). Detecting deception from the body or face. Journal of Personality and Social Psychology, 29, 288-298. 
APPLYING DECEPTION DETECTION TO TRUE AND FALSE CONFESSIONS

Ekman, P., Friesen, W. V., \& O’Sullivan, M. (1988). Smiles when lying. Journal of Personality and Social Psychology, 54, 414-420.

Ekman, P., \& O’Sullivan, M. (1991). Who can catch a liar? American Psychologist, 46 (9), 913920.

Evans, J. R., Michael, S. W., Meissner, C. A., \& Brandon, S. E. (2013). Validating a new assessment method for deception detection: Introducing a Psychologically Based Credibility Assessment Tool. Journal of Applied Research in Memory and Cognition, 2(1), 33-41.

Faul, F., Erdfelder, E., Lang, A.-G., \& Buchner, A. (2007). G*Power 3: A flexible statistical power analysis program for the social, behavioral, and biomedical sciences. Behavior Research Methods, 39, 175-191.

Federal Registrar (2015, March). Annual Determination of Average Cost of Incarceration. Washington, DC: Department of Justice. Retrieved from: https://www.federalregister.gov/articles/2015/03/09/2015-05437/annual-determinationof-average-cost-of-incarceration.

Frank, M. G., \& Feeley, T. H. (2003). To catch a liar: Challenges for research in lie detection training. Journal of Applied Communication Research, 31(1), 58-75.

Feeley, T. H., \& deTurck, M. A. (1997, May). Perceptions of communications as seen by the actor and as seen by the observer: The case of lie detection. Paper presented at the International Communication Association Annual Conference, Montreal, Canada.

Feeley, T. H., \& deTurck, M. A. (1998). The behavioral correlates of sanctioned and unsanctioned deceptive communication. Journal of Nonverbal Behavior, 22, 189-204.

Festinger, L. (1957). A Theory of cognitive dissonance. Stanford, CA: Stanford University Press. 
APPLYING DECEPTION DETECTION TO TRUE AND FALSE CONFESSIONS

Fuller, C. M., Biros, D. P., Burgoon, J., \& Nunamaker, J. (2013). An examination and validation of linguistic constructs for studying high-stakes deception. Group Decision and Negotiation, 22(1), 117-134.

Fuller, C. M., Biros, D. P., \& Wilson, R. L. (2009). Decision support for determining veracity via linguistic-based cues. Decision Support Systems, 46 (3), 695-703.

Garrett, B. (2010). The substance of false confessions. Stanford Law Review, 62(4), 1051-1119.

Garrido, E., Masip, J., \& Herrero, C. (2004). Police officers' credibility judgements: Accuracy and estimated ability. International Journal of Psychology, 39(2), 254-275.

Goldman-Eisler, F. (1968). Psycholinguistics: Experiments in spontaneous speech. New York, NJ: Double day.

Gudjonsson, G.H. (2003). The science of interrogations and confessions: A handbook. Chichester, England: Wiley.

Hancock, J. (2007). Digital Deception: When, where, and how people lie online. In K. McKenna, T. Postmes, U. Reips, \& A. Joinson (Eds.), Oxford handbook of internet psychology (pp. 287-301). Oxford: Oxford University Press.

Hartwig, M., Granhag, P. A., \& Luke, T. (2014). Strategic use of evidence during investigative interviews: The state of the science. In: Raskin, D., editor. Credibility Assessment: Scientific Research and Applications. Academic Press; 2014. p. 1-36.

Hartwig, M., Granhag, P., Strömwall, L., \& Vrij, A. (2004). Police officers’ lie detection accuracy: Interrogating freely versus observing video. Police Quarterly, 7(4), 429-456.

Hyman, I. E., Husband, T. H., \& Billings, F. J. (1995). False memories of childhood experiences. Applied Cognitive Psychology, 9, 181-197. 
APPLYING DECEPTION DETECTION TO TRUE AND FALSE CONFESSIONS

Inbau, F. E., Reid, J. E., Buckley, J. P., \& Jayne (2001). Criminal Interrogation and Confessions (4th. ed.). Gaithersburg, MD: Aspen.

Janux (Producer). 2014. Understanding and Detecting Deception [YouTube Playlist]. Available from https://www.youtube.com/playlist?list=PLTve54sz-eh-HI_Qr6TwEShHMST2wdPP.

Jenkins, S. (2013). Secondary victims and the trauma of wrongful conviction: Families and children's perspectives on imprisonment, release and adjustment. Australia \& New Zealand Journal of Criminology, 64(1), 119-137.

John E. Reid \& Associates, Inc. (2004). Interviewing and Interrogation. Retrieved January 7 , 2009, from http://www.reid.com/training_programs/interview_overview.html

Johnson, M. K. (1988). Reality monitoring: An experimental phenomenological approach. Journal of Experimental Psychology, 117 (4), 390-394.

Johnson, M. K. \& Raye, C. L. (1981). Reality monitoring. Psychological Review, 88 (1), 67-85.

Kassin, S. M. (2005). On the psychology of confessions: Does innocence put innocents at risk? American Psychologist, 60(3), 215-228.

Kassin, S. M. (2008). False Confessions: Causes, consequences, and implications for reform. Current Directions in Psychological Science, 17(4), 249-253.

Kassin, S. M., Appleby, S. C., \& Perillo, J. T. (2010). Interviewing suspects: Practice, science, and future directions. Legal and Criminological Psychology, 15(1), 39-55.

Kassin, S. M., Drizin, S. A., Grisso, T., Gudjonsson, G. H., Leo, R. A., \& Redlich, A. D. (2010). Police-induced confessions: Risk factors and recommendations. Law and Human Behavior, 34(1), 3-38. 
APPLYING DECEPTION DETECTION TO TRUE AND FALSE CONFESSIONS

Kassin, S. M., \& Fong, C. T. (1999). “I'm innocent!”: Effects of training on judgments of truth and deception in the interrogation room. Law and Human Behavior, 23(5), 499.

Kassin, S. M., Goldstein, C. C., \& Savitsky, K. (2003). Behavioral confirmation in the interrogation room: on the dangers of presuming guilt. Law and Human Behavior, 27(2), 187.

Kassin, S. M. \& Kiechel, K. L. (1996). The social psychology of false confessions: Compliance, internalization, and confabulation. Psychological Science, 7(3), 125-128.

Kassin, S. M., Leo, R. A., Meissner, C. A., Richman, K. D., Colwell, L. H., Leach, A.-M., \& La Fon, D. (2007). Police interviewing and interrogation: a self-report survey of police practices and beliefs. Law and Human Behavior, 31(4), 381.

Kassin, S. M., Meissner, C. A., Norwick, R. J. (2005). 'I'd Know a False Confession If I Saw One": A comparative study of college students and police investigators. Law and Human Behavior, 29(2), 211-227.

Kassin, S. M. \& Neumann, K. (1997) On the power of confession evidence: An experimental test of the fundamental difference hypothesis. Law and Human Behavior, 21(5), 469-484.

Kassin, S. M., \& Wrightsman, L. S. (1985). Confession evidence. In S. M. Kassin \& L. S. Wrightsman (Eds.) The psychology of evidence and trial procedure, (pp. 67-94). Beverly Hills: Sage Publications.

Köhnken, G. (1987). Training police officers to detect deceptive eyewitness statements: Does it work? Social Behaviour, 2(1), 1-17.

Köhnken, G. (2004). Statement validity analysis and the 'detection of the truth'. In P. A. Granhag \& L. A. Strömwall (Eds.), Detection of deception in forensic contexts (pp. 4163). Cambridge: Cambridge University Press. 
Kraut, R. (1980). Humans as Lie Detectors. Journal of communication, 30(4), 209-218.

Krzewinski, L. M. (2002). But I didn't do it: Protecting the rights of juveniles during interrogation. Boston College Third World Law Journal, 22(2), 355-387.

Leach, A. (2006).The reliability of "intuitive" lie detection performance (Doctoral Dissertation, Queen's University). Retrieved from http://search.proquest.com/docview/622016338?accountid=13265.

Leach, A. M., Talwar, V., Lee, K., Bala, N., \& Lindsay, R. C. L. (2004). "Intuitive" lie detection of children's deception by law enforcement officials and university students. Law and Human Behavior, 28(6), 661.

Lee, Z., Klaver, J. R., \& Hart, S. D. (2008). Psychopathy and verbal indicators of deception in offenders. Psychology, Crime \& Law, 14, 73-84.

Levine, T. R., Park, H. S., \& McCornack, S. A. (1999). Accuracy in detecting truths and lies: Documenting the "veracity effect". Communications Monographs, 66(2), 125-144.

Levine, T. R., Feeley, T. H., McCornack, S. A., Hughes, M., \& Harms, C. M. (2005). Testing the effects of nonverbal behavior training on accuracy in deception detection with the inclusion of a bogus training control group. Western Journal of Communication, 69(3), $203-217$.

Levine, T. R., Kim, R. K., \& Blair, J.P. (2010). (In) accuracy at detecting true and false confessions and denials: An initial test of a projected motive model of veracity judgements. Human Communication Research, 36(1), 82-102.

Leo, R. A. (1996). Miranda's revenge: Police interrogation as a confidence game. Law and Society Review, 30, 259-288.

Leo, R. A. (2008). Police interrogation and American justice. Harvard University Press. 
APPLYING DECEPTION DETECTION TO TRUE AND FALSE CONFESSIONS

Loftus, E. F. (1997). Creating childhood memories. Applied Cognitive Psychology, 11, S75-S86.

Mann, S., Vrij, A., Leal, S., Granhag, P. A., Warmelink, L., \& Forrester, D. (2012). Windows to the soul? Deliberate eye contact as a cue to deceit. Journal of Nonverbal Behavior, 36(3), 205-215.

Masip, J., Sporer, S., Garrido, E. \& Herrero, C. (2005). The detection of deception with the reality monitoring approach: A review of the Empirical Evidence. Psychology, Crime \& Law, 11(1), 99-122.

Meissner, C. A., \& Kassin, S. M. (2002). "He's guilty!”: Investigator bias in judgments of truth and deception. Law and Human Behavior, 26(5), 469.

Meissner, C. A., \& Kassin, S. M. (2004). You're guilty, so just confess! In Interrogations, confessions, and entrapment (pp. 85-106). Springer. Retrieved from http://link.springer.com/chapter/10.1007/978-0-387-38598-3_4

Meservy, T. O., Jensen, M. L., Kruse, J., Burgoon, J. K., Nunamaker Jr, J. F., Twitchell, D. P., Metaxas, D. N. (2005). Deception detection through automatic, unobtrusive analysis of nonverbal behavior. Intelligent Systems, 20(5), 36-43.

Meyers, B., Latter, R., \& Abdollahi-Arena, M. K. (2006). The court of public opinion: Lay perceptions of polygraph testing. Law and Human Behavior, 30, 509-523.

Ofshe, R. J. \& Leo, R. A. (1997). The social psychology of police interrogation: The theory and classification of true and false confessions. Studies in Law, Politics, and Society, 16, 189254.

Owen-Kostelnik, J., Reppucci, N.D., \& Meyer, J.R. (2006). Testimony and interrogation of minors: Assumptions about maturity and morality. American Psychologist, 61, 286-304. 
APPLYING DECEPTION DETECTION TO TRUE AND FALSE CONFESSIONS

Porter, S., \& ten Brinke, L. (2008). Reading between the lies: Identifying concealed and falsified emotions in universal facial expressions. Psychological Science, 19, 508-514.

Porter, S., \& ten Brinke, L. (2009). Dangerous decisions: A theoretical framework for understanding how judges assess credibility in the courtroom. Legal and Criminological Psychology, 14, 119-134.

Porter S. \& ten Brinke, L. (2010). The Truth about Lies: What works in detecting high-stakes deception? Legal and Criminological Psychology, 15, 57-75.

Porter, S., \& Yuille, J. C. (1995). Credibility assessment of criminal suspects through statement analysis. Psychology, Crime \& Law, 1, 319-231.

Porter, S., \& Yuille, J. C. (1996). The language of deceit: An investigation of the verbal cues to deception in the interrogation context. Law and Human Behavior, 20, 443-458.

Porter, S., Yuile, J. C. \& Lehman, D. R. (1999). The nature of real, implanted, and fabricated memories for emotional childhood events: Implications for the recovered memory debate. Law and Human Behavior, 23, 517-537

Redlich, A. D., Kulish, R., Steadman, H. J. (2011). Comparing true and false confessions among persons with serious mental illness. Psychology, Public Policy, and Law, 17(3), 394-418.

Russano, M. B., Meissner, C. A., Narchet, F. M., \& Kassin, S. M. (2005). Investigating true and false confession within a novel experimental paradigm. Psychological Sciences, 16, 481486.

Scheck, B., Neufeld, P., \& Dwyer, K. (2000). Actual Innocence. Harden City, NY: Doubleday.

Sigurdsson, J. F., \& Gudjonsson, G. H. (1996). The relationship between types of claimed false confession made and the reasons why suspects confess to the police according to the 
APPLYING DECEPTION DETECTION TO TRUE AND FALSE CONFESSIONS

Gudjonsson Confession Questionnaire (GCQ). Legal and Criminological Psychology, 1, 259-269.

Smith, V. L., \& Clark, H. H. (1993). On the course of answering questions. Journal of Memory and Language, 32, 25-38.

Sporer, S. L. (1997). The less travelled road to truth: Verbal cues in deception detection in accounts of fabricated and self-experienced events. Applied Cognitive Psychology, 11, 373-397.

Sporer, S. L., \& Schwandt, B. (2006). Paraverbal indicators of deception: A meta-analytic synthesis. Applied Cognitive Psychology, 20, 421-446.

Sullivan, R. (1990, July 24). Detective says he tricked jogger suspect. The New York Times. Retrieved from http://www.nytimes.com/1990/07/24/nyregion/detective-says-he-trickedjogger-suspect.html.

ten Brinke, L. \& Porter, S. (2013). Discovering deceit: Applying laboratory and field research in the search for truthful and deceptive behavior. In Cooper, B. et al. (Eds.) Applied Issues in Investigative Interviewing, Eyewitness Memory, and Credibility Assessment (221235). New York, NY: Springer.

Tillbrook, C., Mumley, D., Grisso, T. (2003). Avoiding expert opinions on the ultimate legal question: The case for integrity. Journal of Forensic Psychology Practice, 3(3), 77-87.

Undeutsch, U. (1982). Statement reality analysis. In A. Trankell (Ed.), Reconstructing the past: The role of psychologists in criminal trials (pp. 27-56). Stockholm: Norstedts.

Volbert, R. \& Banse, R. (2014). How can psychological research assist legal practice? European Psychologist, 19(3), 159-161. 
APPLYING DECEPTION DETECTION TO TRUE AND FALSE CONFESSIONS

Vrij, A. (2000). Detecting Lies and Deceit: The Psychology of Lying and the Implications for Professional Practice. London: Wiley.

Vrij, A. (2008a). Detecting lies and deceit: Pitfalls and opportunities. London: John Wiley \& Sons.

Vrij, A. (2008b). Nonverbal dominance versus verbal accuracy in lie detection: A plea to Change Police Practice. Criminal Justice and Behavior, 35(10), 1323-1336.

Vrij, A., \& Baxter, M. (1999). Accuracy and confidence in detecting truths and lies in elaborations and denials: Truth bias, lie bias and individual differences. Expert Evidence, 7(1), 25-36

Vrij, A., Edward, K., \& Bull, R. (2001). Police officers' ability to detect deceit: The benefit of indirect deception detection measures. Legal and Criminological Psychology, 6(2), 185196.

Vrij, A., Fisher, R., Mann, S., \& Leal, S. (2006). Detecting deception by manipulating cognitive load. Trends in cognitive sciences, 10(4), 141-142.

Vrij, A., Mann, S., Fisher, R., Leal, S., Milne, R. \& Bull, R. (2008). Increasing cognitive load to facilitate lie detection: The benefit of recalling an event in reverse order. Law and Human Behavior, 32, 253-265.

Vrij, A., Mann, S., Kristen, S. \& Fisher R. (2007). Cues to deception and ability to detect lies as a function of police interview styles. Law and Human Behavior, 31, 499-518.

Walczyk, J. J., Schwartz, J. P., Clifton, R., Adams, B., Wei, M. I. N., \& Zha, P. (2005). Lying person to person about life events: a cognitive framework for lie detection. Personnel Psychology, 58, 141-170. 
Warden, R., \& Drizin, S. A. (Eds.). (2009). True stories of false confessions. Evanston, IL: Northwestern University Press.

Willén, R. M. \& Strömwall, L. A. (2012). Offenders' uncoerced false confessions: A new application of statement analysis? Legal and Criminological Psychology, 12, 346-359.

Williams, J. W. (2000). Interrogating justice: A critical analysis of the police interrogation and its role in the criminal justice process. Canadian Journal of Criminology, 42, 209-240.

Wilson, P. J. (2003). Wrongful convictions: Lessons learned from the Sophonow Public Inquiry.Canadian Police College.

White, W. S. (2003). Confessions in capital cases. University of Illinois Law Review, 2003, 9791036.

Zuckerman, M., DePaulo, B. M., \& Rosenthal, R. (1981). Verbal and nonverbal communication of deception. In L. Berkowitz (Ed.), Advances in experimental social psychology (pp. 159). New York: Academic.

Zuckerman, M., Koestner, R. \& Driver, R. (1981). Beliefs about cues associated with deception. Journal of Nonverbal Behavior, 6(2), 105-114. 